\title{
Recent Advancements on COVID-19: A Comprehensive Review
}

\author{
Heshu Sulaiman Rahman (iD) 1,2 \\ Darya Saeed Abdulateef (iD) \\ Narmin Hamaamin Hussen ${ }^{3}$ \\ Aso Faiq Salih ${ }^{4}$ \\ Hemn Hassan Othman (iD) ${ }^{5}$ \\ Trifa Mahmood Abdulla (D) \\ Shirwan Hama Salih Omer' \\ Talar Hamaali \\ Mohammed' \\ Mohammed Omar \\ Mohammed iD ${ }^{6}$ \\ Masrur Sleman $\mathrm{Aziz}^{7}$ \\ Rasedee Abdullah (iD) ${ }^{8}$ \\ 'Department of Physiology, College of \\ Medicine, University of Sulaimani, \\ Sulaimaniyah, Republic of Iraq; ' ${ }^{2}$ Department \\ of Medical Laboratory Sciences, Komar \\ University of Science and Technology, \\ Sulaimaniyah, Republic of Iraq; ${ }^{3}$ Department \\ of Pharmacognosy and Pharmaceutical \\ Chemistry, College of Pharmacy, University \\ of Sulaimani, Sulaimaniyah, Republic of Iraq; \\ ${ }^{4}$ Department of Pediatrics, College of \\ Medicine, University of Sulaimani, \\ Sulaimaniyah, Republic of Iraq; ${ }^{5}$ Department \\ of Pharmacology and Toxicology, College of \\ Pharmacy, University of Sulaimani, \\ Sulaimaniyah, Republic of Iraq; ${ }^{6}$ Department \\ of Medicine, College of Medicine, University \\ of Sulaimani, Sulaimaniyah, Republic of Iraq; \\ ${ }^{7}$ Department of Biology, College of \\ Education, Salahaddin University, Erbil, \\ Republic of Iraq; ${ }^{8}$ Faculty of Veterinary \\ Medicine, Universiti Putra Malaysia, UPM, \\ Serdang, Selangor, 43400, Malaysia
}

Correspondence: Heshu Sulaiman Rahman Department of Physiology, College of Medicine, University of Sulaimani,

Sulaimaniyah, 4600I, Republic of Iraq

Tel +9647726159598

Email heshu.rhaman@univsul.edu.iq

Aso Faiq Salih

Department of Pediatrics, College of

Medicine, University of Sulaimani,

Sulaimaniyah, Republic of Iraq

Email aso.salih@univsul.edu.iq

\begin{abstract}
Over the last few decades, there have been several global outbreaks of severe respiratory infections. The causes of these outbreaks were coronaviruses that had infected birds, mammals and humans. The outbreaks predominantly caused respiratory tract and gastrointestinal tract symptoms and other mild to very severe clinical signs. The current coronavirus disease-2019 (COVID-19) outbreak, caused by the novel severe acute respiratory syndrome coronavirus 2 (SARS-CoV-2), is a rapidly spreading illness affecting millions of people worldwide. Among the countries most affected by the disease are the United States of America (USA), India, Brazil, and Russia, with France recording the highest infection, morbidity, and mortality rates. Since early January 2021, thousands of articles have been published on COVID-19. Most of these articles were consistent with the reports on the mode of transmission, spread, duration, and severity of the sickness. Thus, this review comprehensively discusses the most critical aspects of COVID-19, including etiology, epidemiology, pathogenesis, clinical signs, transmission, pathological changes, diagnosis, treatment, prevention and control, and vaccination.
\end{abstract}

Keywords: recent advancements, COVID-19, pandemic infection, global outbreak, a comprehensive review

\section{Introduction}

The COVID-19 pandemic, first identified in December 2019 in Wuhan city, Hubei province, China and has spread to most world regions, is caused by the SARS-CoV-2. ${ }^{1}$ The infection is efficiently transmitted from animal to human and from human to human through droplets or direct contact. Infected humans are either asymptomatic or may show mild, moderate, or severe symptoms. ${ }^{2}$ However, approximately $80 \%$ of patients' present mild clinical signs and the overall case fatality rate from the infection at about $2.3 \%$. The severity of the disease increased with age and the presence of comorbidities, including cardiovascular diseases, diabetes, chronic respiratory disease, hypertension, and cancer. The fatality rate of COVID-19 patients aged over 80 years was reported at $14.8 \%$. There is no accurate estimate of the rate of asymptomatic carriers of the COVID-19.,4

COVID-19 is similar to severe acute respiratory syndrome coronavirus 1 (SARS-CoV-1) and Middle East respiratory syndrome coronavirus (MERS-CoV) infections with bats as the probable species from which the virus originates. The SARS-CoV shares $96 \%$ whole-genome identity with the bat, Rhinolophus affinis, CoV RaTG13. ${ }^{5,6}$ Similar to SARS-CoV and MERS-CoV, the SARS-CoV-2 first infects intermediate hosts, such as masked palm civets (Paguma larvata), before infecting humans. ${ }^{7}$ In April 2020, Chinese researchers discovered that the pangolin species are also the intermediate hosts of SARS-CoV-2. However, there is only $92 \%$ similarity in whole-genome genetic material between the pangolin coronavirus and 
SARS-CoV-2, which is insufficient to suggest that the pangolins are the intermediate host for the human infection. ${ }^{8,9}$

Currently, the zoonotic repertoire of COVID-19 is not clearly established because of the variability in the behaviour of the infection in various animal species. Cats are susceptible, while dogs and ferrets only showed intermediate vulnerability to the disease. The virus does not replicate well in dogs, pigs, chickens or ducks. It appears that the body temperatures of the host species determine the predilection of SARS-CoV-2 infection. The mean body temperatures of the human and cat hosts are lower than those of the more resistant hosts. ${ }^{10}$

It is now clear that like SARS-CoV-1, the SARS-CoV2 infects humans through the cell membrane receptor, angiotensin-converting enzyme 2 (ACE2). ACE2 is usually highly expressed in the organs of humans, including the respiratory and gastrointestinal tracts, blood vessels, bone marrow, spleen, thymus, lymph node, liver, kidney, and brain. The receptor regulates cross-species and human-to-human transmissions through its interactions with the viral S-glycoprotein S1 and S2 subunits. ${ }^{11,12}$

The median incubation period of SARS-CoV-2 is also similar to SARS-CoV-1, and $97.5 \%$ of patients develop symptoms within 14 days of infection. In infected patients, it is difficult to determine when SARS-CoV-2 conditions begin because the incubation periods vary with cases. ${ }^{13}$

\section{Genomic Structure of SARS-CoV-2}

Coronaviruses are a large group comprising alpha, beta, delta, and gamma coronaviruses. The SARS-CoV-2 is a beta coronavirus, an enveloped, positive-sense, singlestranded RNA virus belonging to Coronaviridae family. ${ }^{14}$ Although the alpha and beta coronavirus are mainly found in bats, they can also infect other species, including humans, camels, and rabbits. ${ }^{15}$ The beta-coronaviruses, SARS-CoV-1, SARS-CoV-2, and MERS-CoV, are endemic in humans, inducing fever and severe and potentially fatal respiratory tract infections. Among the beta coronaviruses, SARS-CoV-2 showed the most significant infectivity but with a lower rate of case fatality. ${ }^{16,17}$

Structurally, the SARS-CoV-2 is approximately $79 \%$ and $50 \%$ in identity with SARS-CoV-1 and MERS-CoV, respectively. The SARS-CoV-2 is more similar to 2 batderived SARS-like coronaviruses, SL-CoVZC45 and SLCoVZXC21, with $87.9 \%$ and $87.2 \%$ sequence identity, respectively. ${ }^{18,19}$ The SARS-CoV-2 encodes two large structural polyproteins, the papain-like protease, $\mathrm{PL}^{\text {pro, }}$ and 3-chymotrypsin-like protease, $3 \mathrm{CL}^{\text {pro }}$ or protease$\mathrm{M}^{\text {pro }}$. These polyproteins are spike surface glycoproteins, matrix, small envelope, and nucleocapsid proteins that are essentially involved in the maturation, infectivity, and lifecycle of the virus. ${ }^{20}$ Spike proteins target host ACE2 receptor-binding domains; ${ }^{21}$ thus, they are potential targets for antiviral drugs. The protease- $\mathrm{M}^{\text {pro }}$ is a potential target for the screening of COVID-19 drug candidates. ${ }^{22}$

\section{Tropism}

In infected humans, the SAR-CoV-2 has been isolated from the alveolar epithelial cells, macrophages, capillaries, renal glomerular endothelial cells, brain blood vessels, colonic mucosa, and the skin. ${ }^{23}$ In the lung, the SARCoV-2 infect ciliated, mucus-secreting, and club cells of the bronchial epithelium and type 1 pneumocytes. ${ }^{24}$

\section{Incubation Period}

Knowledge of the incubation period of coronaviruses is essential for epidemiological case definition, assessment of entry, screening, and contact tracing, and finally, to determine the appropriate duration of the quarantine. ${ }^{13,25-27}$ There are variable reports on the incubation period of coronaviruses (Table 1).

\section{Clinical Signs}

The period from the onset of COVID-19 symptoms to death ranged from 6 to 41 days with a median of 14 days. This period is dependent on the age of the patient and the status of the patient's immune system, which is shorter among patients $>70$-years old than those $<70$-years old. $^{28}$ The clinical signs among $80 \%$ of COVID-19 patients ranged from mild to non-specific influenza-like symptoms. ${ }^{29}$ Generally, the clinical features of confirmed COVID-19 patients include fever and respiratory

Table I Reported Incubation Period of Coronaviruses

\begin{tabular}{|l|l|l|l|}
\hline \multirow{2}{*}{ Coronavirus } & \multicolumn{2}{|c|}{ Incubation Period } & \multirow{2}{*}{ Reference } \\
\cline { 2 - 3 } & Median/Day & $\begin{array}{l}\text { Range } \\
(95 \% \text { Cl)/Day }\end{array}$ & \\
\hline SARS-CoV-2 & 5.1 & $4.5-5.8$ & {$[13]$} \\
SARS-CoV-2 & 6.4 & $2.1-11.1$ & {$[25]$} \\
SARS-CoV-2 & 5.0 & $2.0-14.0$ & {$[139]$} \\
SARS-CoV-2 & 5.2 & $4.1-7.0$ & {$[118]$} \\
SARS-CoV-I & 5.0 & $2.0-14.0$ & {$[26]$} \\
MERS-CoV (South Korea) & 6.9 & $6.3-7.5$ & {$[27]$} \\
MERS-CoV (Saudi Arabia) & 5.0 & $4.0-6.6$ & {$[27]$} \\
\hline
\end{tabular}


symptoms, such as cough, dyspnea, shortness of breath, sore throat, sputum formation, myalgia, headache, nausea, abdominal pain, vomiting, diarrhoea, and hemoptysis. ${ }^{30,31}$ These clinical signs are often not distinguishing features for COVID-19 because they largely overlap with those of other respiratory infections. However, symptoms like fever, cough, and shortness of breath are considered typical of COVID-19. ${ }^{32}$ These symptoms may progress to acute respiratory distress syndrome (ARDS) that requires intensive care. $^{33}$

Cutaneous manifestations including urticarial rash, morbilliform-maculopapular, papulovesicular, chilblainlike, livedo reticularis/livedo racemosa like and purpuricvasculitic lesions are now reported to be among the clinical signs of COVID-19. These manifestations may be explained by the discovery of the SAR-CoV-2 spike protein in blood vessels and sweat gland epithelium of patients with acral purpuric lesions. ${ }^{34}$

\section{Image Finding}

At the beginning of this pandemic, thoracic radiology was often used to evaluate patients with COVID-19. However, it may not be sensitive to early or mild disease $e^{35,36}$ and regions of peak COVID-19 pandemic, CT was the better option. ${ }^{37,38}$ Some hospitalized patients may show bilateral lung ground-glass opacity (GGO) on CT. The GGO and consolidation, pleural effusion, calcifications, mediastinal lymphadenopathy and enlargement of pulmonary vessels in areas of new lung infiltrates are suggested to be good radiological predictors of lung impairment in patients severely infected with COVID-19. However, precautions should be taken when using CT for COVID-19 screening because this diagnostic technique is often fraught with false-negative and false-positive results. ${ }^{39,40}$

\section{Disease Susceptibility}

Susceptibility to COVID-19 seems to be associated with age, sex, and the presence of comorbidities. The disease is usually mild in young patients less than 19 years of age, with flu-like symptoms and rapidly resolving fever. ${ }^{41,42}$ This is particularly true for those without underlying conditions like impaired lung function or immunosuppression.

\section{Age}

Initially, most COVID-19 cases were among adults, with very few reported pediatric patients. However, a month into the epidemic, a novel multisystem inflammatory syndrome in children (MIS-C) emerged, and some studies suggested that MIS-C is a secondary consequence of SARS-CoV-2 infection in which over $70 \%$ of MIS-C patients test positive for serum antibodies against SARS$\mathrm{CoV}-2$ and test negative for the presence of viral RNA. ${ }^{43}$ In this regard, a recent prospective cohort study showed that COVID-19 is not uncommon in paediatrics (especially among children aged 1-4 years). It presents as either primary, MIS-C or Kawasaki Disease (KD). Most deaths and ICU outcomes were related to MIS-C due to cardiac involvement (pericardial effusion and left ventricular dysfunction). ${ }^{44}$ Among the age groups, the elderly are most susceptible to COVID-19. ${ }^{45}$ Infected children usually present, at most, with mild symptoms and diagnosis of the diseases in this population often requires epidemiological clues about exposure. ${ }^{46}$ The reasons for the condition being mild COVID-19 in children are largely unknown.

\section{Gender}

Most studies supported that symptomatic COVID-19 is more prevalent in men than women. Among the factors that have been attributed to the sex differences in the susceptibility to COVID-19 include higher expression of ACE2 receptors, poorer immune response, and lack of maintaining responsible COVID-19 prevention lifestyle among men than women. The more rampant smoking and drinking habits among men than women are significant susceptibility factors for COVID-19. ${ }^{46}$ On the other hand, it was found that elevated estrogen levels in female COVID-19 patients may reduce the severity and mortality of deaths through an elevation in the innate and humoral response. Furthermore, pre-clinical studies suggest that ACE2 expression may increase the susceptibility of COVID-19 in pregnant patients. ${ }^{47}$ However, a study reported that males and females have the exact prevalence of COVID-19, but male patients have a higher mortality rate than females due to the severity of the disease, independent of age. ${ }^{48}$

\section{Comorbidity}

A high number of individuals with COVID-19 have comorbidities, including poor immunity due to chronic illnesses such as hypertension, diabetes, hypercholesteraemia, malignancy, obstructive sleep apnea, Parkinson's disease, dementia, and delirium, on long-term use of immune-suppressive agents, or had surgeries or organ failure/transplant. These groups of people are not only vulnerable to COVID-19 but also develop a severe disease that is not adequately responsive to treatment and is often fatal. ${ }^{49-54}$ The susceptible population usually develops ARDS. Death ensues in approximately $61.5 \%$ of critically ill patients due to severe 
complications like ARDS, septic shock, coagulation accidents, acute respiratory failure, and multiple systems organ failure (MSOF). In this respect, several drugs to control the comorbidity provide benefits such as dipeptidyl peptidase 4 (DPP4) inhibitor, ${ }^{55}$ glucagon-like peptide-1 receptor agonist (GLP-1RA), ${ }^{56}$ and ACE inhibitor/ARB. ${ }^{57}$

\section{Blood Group}

It has been suggested that there is a link between the blood type of patients and COVID-19 susceptibility and severity. Among patients of various blood groups, those with group O have low risk, while those with group A blood have the highest chance of acquiring COVID- $19^{58}$ Individuals with $\mathrm{Rh}+$ blood type are also at increased risk for COVID-19. ${ }^{59}$ Hence, the results of a meta-analysis of twenty-one studies showed that there is no evidence to indicate the effect of the $\mathrm{O}$ type on disease severity in $\mathrm{CoV}-2$ infection. ${ }^{60}$ On the contrary, a study in Iran showed no association between blood type and Rh type with COVID-19. However, there is an association between age and gender, ${ }^{61}$ and these study outcomes agree with the results of Levi et al., 2020. ${ }^{62}$

\section{Sickle Cell Anaemia and Thalassemia}

Anaemia, in general, ${ }^{63}$ and those resulting from sickle cell $^{64}$ and thalassemia, ${ }^{65}$ leads to the high development of pulmonary embolism (PE). Thus, if with COVID-19, these patients are prone to develop fatal pulmonary infection. Sickle cell anaemia and thalassemia are more common among blacks and South Asian ethnic groups than Caucasians, suggesting that blacks and South Asians are more vulnerable to the acquisition of COVID-19 than Caucasians. ${ }^{66}$

\section{Epidemiology}

On December 30, 2019, a cluster of 27 pneumonia cases, including 7 severe cases of unknown origin in Wuhan city, Hubei province, China, were reported to the National Health Commission of China. In the early stages of this pneumonia, patients developed a severe acute respiratory infection, and some patients rapidly developed acute respiratory distress syndrome. Real-time polymerase chain reaction (RT-PCR) and deep sequencing analysis of lower respiratory tract samples identified SARS-CoV-2. ${ }^{67,68}$

By the end of January 2020, nearly 50,000 confirmed cases were reported in China, and among countries that showed the first confirmed cases were Thailand, Nepal, Republic of Korea, USA, Singapore, France, Vietnam, Canada, Australia, Malaysia, Germany, United Arab
Emirates (UAE), Finland, Italy, Cambodia, Sri Lanka, the Russian Federation, Spain, Sweden, India, and the Philippines. ${ }^{69}$

By the end of February 2020, most countries had begun reporting cases of COVID-19. The patients were aged between 30 and 80 years and usually showed mild infections $(80 \%)$. The fatality rate among these patients was approximately 2\%. On March 11, 2020, the World Health Organization declared the disease pandemic. ${ }^{70}$

Among European countries, Italy was the first to document many COVID-19 cases, with the region of Lombardy severely affected, a total of 17,713 people tested positive for SARSCoV-2, and 1593 admitted to intensive care unit (ICU) between the end of February and the end of March $2020 .^{71}$

By September 25, 2020, there were more than $31,572,774$ cases, 989,981 deaths, and 24,048,380 recovered cases from COVID-19 worldwide. Approximately 535,000 cases and more than 20,600 deaths were reported from the USA alone. The COVID-19 cases kept increasing from primary, secondary, tertiary and infections and reinfection. $^{6,72}$

Up-to-date, approximately $2.5 \times 10^{8}$ infected COVID19 cases are found with $>5 \times 10^{6}$ deaths and $>2.23 \times 10^{6}$ recovered cases worldwide. The largest number of fatalities from the disease is found in the USA, India, Brazil, UK, Russia, Turkey, and France. Among them, Alpha (B.1.1.7), Beta (B.1.351), Gamma (P.1), and Delta (B.1.617.2)-coronavirus have been reported. ${ }^{73}$

\section{Pathophysiology and Pathogenesis}

The COVID-19 virus enters target cells through the cleavage and activation of viral spike protein by the host cell protease, type II transmembrane serine protease (TMPRSS2) ${ }^{74}$ The virus spike subunits engage ACE2 as the cell-entry receptor (Figure 1). ${ }^{75}$ The successful entry of the virus into the cell requires the co-expression on the cell surface of ACE2 and TMPRSS2. ${ }^{75}$

SARS-CoV-2 infections causing COVID-19 is facilitated by the following mechanisms; (1) direct virusmediated cell damage, (2) dysregulation of the ReninAngiotensin-Aldosterone System (RAAS) as a consequence of down-regulation of ACE2 that leads to decreased cleavage of angiotensin I and angiotensin II, (3) endothelial cell damage and thrombo-inflammation, and (4) dysregulation of immune response and hyperinflammation caused by the inhibition of interferon signalling by the virus, $\mathrm{T}$ cell depletion, and the production of pro-inflammatory cytokines, particularly IL-6 and TNF $\alpha^{75}$ 

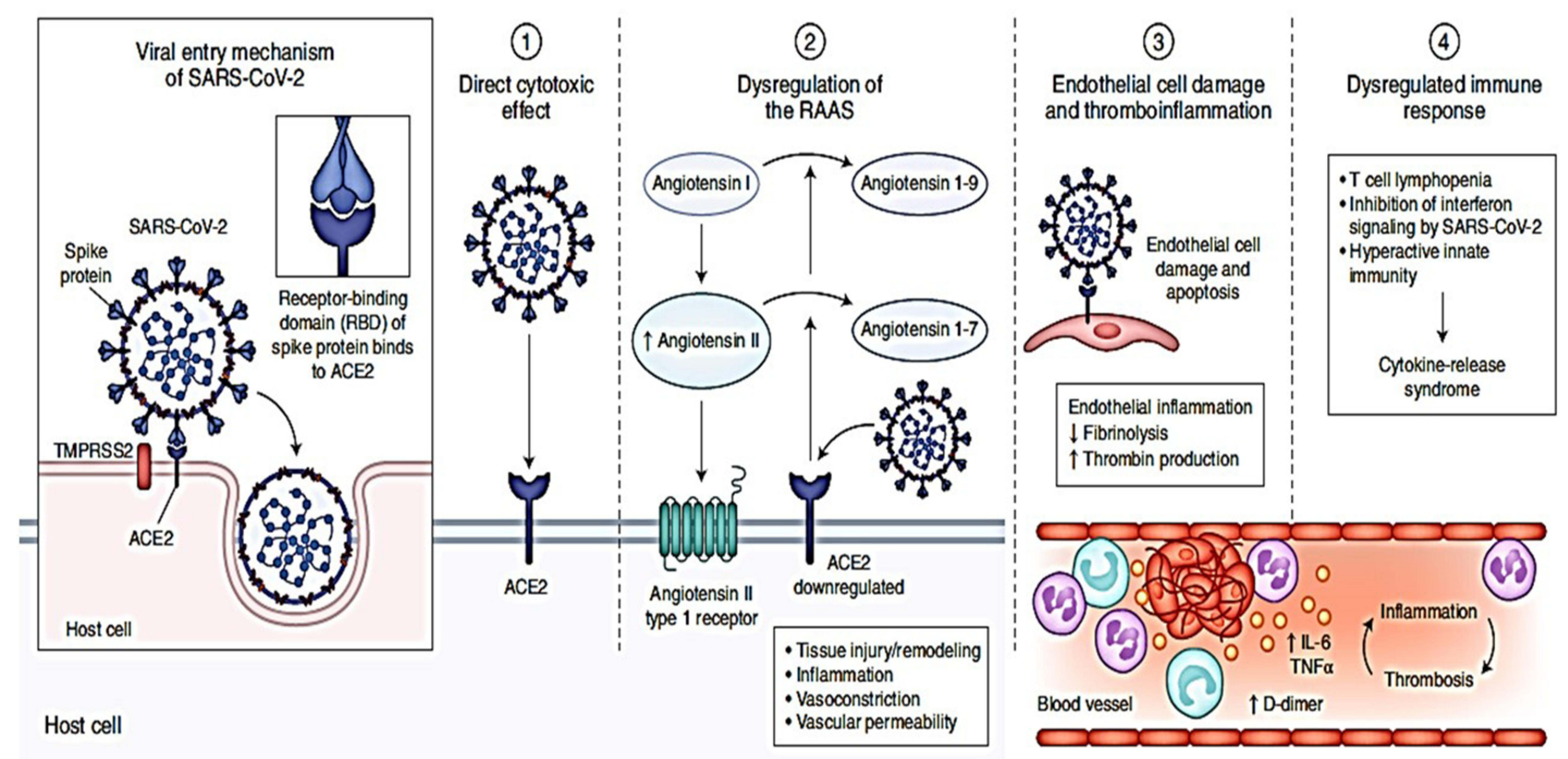

Figure I Pathophysiology of COVID-19 indicate virus entering the host cells through interaction of its spike protein with the entry receptor ACE2 in the presence of TMPRSS2.

Notes: Reproduced by permission from: Gupta A, Madhavan MV, Sehgal K, et al. Extrapulmonary manifestations of COVID-19. Nature Medicine. 2020;26(7):1017-1032. doi:10.1038/s4159I-020-0968-3. ${ }^{75}$ @ Springer Nature America, Inc. 2020. This image is exlcuded from the Creative Commons license: Figure I is copyright protected and excluded from the open access license.

ACE2 is heavily expressed on ciliated airway epithelial cells and alveolar type 2 pneumocytes of the lungs. It is believed that SARS-CoV-2 undergoes hematogenous dissemination via infected pulmonary epithelium. The injured endothelium, while activating the coagulation cascade, also shows increased microvascular permeability. In an attempt to inhibit viral replication and dissemination, the host immune response mediates inflammation and cellular antiviral activity. However, if the immune response is excessive, the patient, especially the young, will show severe symptoms. COVID-19 patients, especially those requiring intensive care, were reported to have high levels of plasma cytokines,${ }^{76}$ including IL-1 $\beta$, IL-1RA, IL-2, IL7, IL-8, IL-9, IL-10, basic FGF2, GCSF, GMCSF, IFN $\gamma$, IP10, MCP1, MIP1 $\alpha$, MIP1 $\beta$, PDGFB, TNF $\alpha$, and VEGFA. ${ }^{77}$

\section{Transmission}

\section{Animal-to-Human Transmission}

Although the infection is zoonotic, the mode of transmission of COVID-19 in humans is not clear. ${ }^{78}$ The bats are suggested to be the reservoir for the human SARS-CoV-2. ${ }^{79}$ Based on codon similarities between the human SARS$\mathrm{CoV}-2$ and the Bungarus multicinctus snake coronavirus, it appears the snakes are also potential reservoirs for the infection. ${ }^{80}$ The Malayan pangolin (Manis javanica) is a natural reservoir of the SARS-CoV-2, and they are suggested to play a significant role in the transmission of COVID-19 to humans. ${ }^{81-83}$

\section{Human-to-Human Transmission}

COVID-19 is known to exhibit human-to-human transmission, ${ }^{84}$ the primary mode of transmission in the current pandemic. ${ }^{85}$ COVID-19 patients spread the disease to those in close contact. ${ }^{86,87}$ However, since many COVID-19 patients are asymptomatic and can serve as carriers, they may have unknowingly transmitted the virus to others. ${ }^{88-90}$ This mode of transmission includes:

\section{Horizontal Transmission}

There are 3 main modes of horizontal transmission of COVID-19 in humans: ${ }^{67,91}$

\section{Direct Contact}

This mode of transmission may occur through direct contact with virus-contaminated objects or surfaces and infecting people through the mouth, nose, or eyes. ${ }^{92,93}$ In addition, a direct correlation between air pollution and COVID-19 was observed. Thus, exposure to indoor 
polluted air is likely to be directly associated with the disease, especially among refugees and migrant workers who live in feeble conditions. However, home isolation for an infected population may be a potential factor to other health problems if the place where they are socially isolated is not adequately ventilated. Therefore, an understanding of the consequences of the relationship between indoor air quality and the COVID-19 pandemic should be considered. ${ }^{94}$

\section{Aerosol}

COVID-19 virus is primarily not airborne. ${ }^{95}$ Instead, the virus is present in the aerosols of expired air, coughs, and sneezes, which are the main media for virus spread ${ }^{42,96,97}$ from COVID-19-positive people. ${ }^{89,98}$ The virus remains viable for at least 3 hours in aerosols and as long as 48 to 72 hours on stainless-steel and plastic surfaces. ${ }^{99}$

\section{Droplet}

Respiratory air typically contains an abundance of droplets of sizes $<5 \mu \mathrm{m}$ in diameter. Coughing and sneezing cause increased expulsion of these droplets from the oral cavity and respiratory tract. In COVID-19 patients, these droplets contain a virus that, if inhaled or ingested, will cause disease. ${ }^{1,99,100}$

\section{Feces and Body Fluids}

COVID-19 transmission may also occur via feces, urine, tears, sweats, and conjunctival secretions. ${ }^{46,101-103}$ The role of feces in the transmission of COVID-19 is unclear. ${ }^{104}$ There are suggestions that the gastrointestinal system is an essential route for the spread of SARS-CoV-2. ${ }^{105}$ Incidentally, there are high expressions of ACE2 in the gastric glandular, colon, ileal, duodenal, and rectal cells, suggesting the virus may spread via the fecal-oral route. ${ }^{58,98}$ Unlike in the respiratory tract, where the clearance of the occurs within 2 weeks, the feces can remain positive for coronavirus RNA for longer than 4 weeks, even after the patient no longer show symptoms of the disease. ${ }^{106}$

\section{Vertical Transmission}

It is believed that COVID-19 can potentially be transmitted vertically due to the high expression of ACE2 receptors in the human maternal-fetal interphase. This indicates that the COVID-19 pandemic puts pregnant women and fetuses at risk of being infected. ${ }^{107,108}$ At the beginning of the disease, cases of vertical COVID-19 transmission were very few and mostly incidental.
However, the potential for vertical transmission of COVID-19 has not been ruled out.

\section{Pathology and Postmortem Changes \\ Lung}

The SARS-CoV-2 primarily targets the respiratory system. ${ }^{109}$ The pathological features of the affected tissues of patients who died with COVID-19 could provide additional information on the pathogenesis and the cause of clinical outcomes of the disease. Carsana et al systematically analyzed lung tissue samples from 38 patients in Northern Italy, who died of COVID-19 between February 29 and March 24, 2020. They discovered that all cases showed exudative and proliferative diffuse alveolar damage with massive capillary congestion, pneumocytic necrosis, hyaline membranes, interstitial and intra-alveolar oedema, type 2 pneumocyte hyperplasia, and squamous metaplasia with atypia. They also discovered that platelet-fibrin thrombi in the small arterial vessels consistent with coagulopathy were common features in COVID-19 patients. Inflammatory infiltrates in the alveolar lumina are composed mainly of macrophages and lymphocytes. Electron microscopy revealed that viral particles were predominantly located in the pneumocytes. The study also showed that $11 \%$ of the patients had bacterial abscesses, and $3 \%$ had a single fungal abscess, which was presumed to have formed after hospital admission. ${ }^{71}$

Postmortem showed that COVID-19 is associated with diffused alveolar damage. This observation was consistent with the histological changes in tissues obtained by transthoracic needle biopsies from dead COVID-19 patients with GGO and respiratory failure. ${ }^{110}$ Lung tissues collected by cryobiopsy from COVID-19 patients within 30 minutes of death showed marked fibrotic lung parenchymal remodelling, characterized by fibroblast proliferation, airspace obliteration, and micro-honeycombing. ${ }^{111}$ During lung lobectomies, edema, prominent proteinaceous exudates, vascular congestion, and inflammatory clusters with fibrinoid material and multinucleated giant cells were discovered in two COVID-19 patients. ${ }^{112}$ It is suggested that alveolar macrophage infiltration in COVID-19 is the driver of the cytokine storm, causing damage to the pulmonary tissues, heart and lung, and leading to multiple organ failures. ${ }^{113}$

\section{Liver}

The livers of patients that died of COVID-19 showed pathological lesions including myocardial hypertrophy, 
atherosclerosis, general interstitial fibrosis, mild myocardial edema, and atypical, minimal, focal, and perivascular interstitial fibrosis. Some patients showed low-grade interstitial mononuclear cell infiltrations, lymphocytic myocarditis, and endotheliosis. COVID-19 also causes liver disorder with changes including hepatic congestion, steatosis, cirrhosis, patchy hepatic necrosis, Kupffer cell hyperplasia, mild sinusoidal dilatation, hepatic endotheliosis. ${ }^{114,115}$

Brain

There are only a few studies on neuropathological changes in COVID-19 patients. One study showed that among the neuropathological manifestations in COVID-19 were microthrombi and acute infarcts, hypoxic changes with no specific pathology or perivascular lymphocytic infiltration in the brainstem. ${ }^{116}$ During the postmortem, the brain of COVID-19 patients revealed mild brain swelling and disseminated hemorrhagic lesions throughout cerebral hemispheric white matter, ranging from $1.0 \mathrm{~mm}$ to $1.0 \mathrm{~cm}$ in diameter, macrophage infiltration, and foci of intraparenchymal blood that disrupted the white matter. ${ }^{117}$ Other histopathological changes in the brain include subarachnoid hemorrhages, hydrocephalus internus with acute hypoxicischemic encephalopathy of the hippocampus, and cerebral oedema. ${ }^{118}$ Viral RNA was detected in the olfactory bulb of the brain stem. ${ }^{119}$ COVID-19 patients also developed acute ischaemic stroke $(4.6 \%)$ and intracerebral hemorrhage $(0.5 \%)$, with the elderly at higher risk than young patients of developing cerebrovascular disease (CVD). ${ }^{120}$

\section{Kidneys}

The kidneys of COVID-19 patients showed diffused proximal tubule injury with the loss of brush border, nonisometric vacuolar degeneration, and frank necrosis. Hemosiderin granules and pigmented casts were present in their kidneys and erythrocyte aggregates, without platelet or fibrinoid material, obstructing the capillaries in some old patients. Using electron microscopy, clusters of coronavirus-like particles with distinctive spikes were demonstrated in the proximal tubular epithelium and podocytes. $^{109}$

\section{Coagulation Abnormality}

Patients with severe COVID-19 are prone to develop thrombotic and/or thromboembolic events, such as PE, deep vein thrombosis (DVT), ${ }^{114}$ arterial thrombosis, hypercoagulable coagulopathy, ${ }^{121}$ and intracatheter thrombosis, ${ }^{122}$ as well as disseminated intravascular coagulopathy (DIC). ${ }^{123}$ These conditions showed that COVID-19 patients are predisposed to thrombotic diseases. However, the thrombotic risk is influenced by race and ethnicity, as evident by the fact that Chinese are at significantly lower risk for these manifestations of COVID-19 than Caucasians. Thrombosis occurs primarily in the pulmonary circulation due to in situ thrombi formation but without apparent embolism. Whether or not the formation of thrombi indicates COVID-19-related DIC is not clear. ${ }^{124}$

\section{Diagnosis}

Microbiological tests are mandatory in the diagnosis of COVID-19. ${ }^{125}$ Among people who should undergo testing include those who developed fever and/or respiratory symptoms or showed lower respiratory tract (LRT) infection. The likelihood of a person contracting COVID-19 is higher in individuals with travel history or those in contact with suspected or confirmed cases of COVID-19. ${ }^{125}$ However, due to limitations in testing capacity, $\mathrm{CDC}^{126}$ and the Infectious Diseases Society of America (IDSA) ${ }^{127}$ had listed the patient priorities for COVID-19 testing, including symptomatic severely ill individuals, front-liners, and individuals with risk factors.

\section{Investigations and Testing for COVID-I 9 \\ Real Time-Polymerase Chain Reaction (RT-PCR) Test}

The current tests used to diagnose COVID-19 cases are based on molecular viral and antiviral antibody assays. ${ }^{128,129} \mathrm{On}$ January 7, 2020, Chinese researchers shared the entire genetic sequence of SARS-CoV-2 through the National Institutes of Health GenBank ${ }^{130}$ and the Global Initiative on Sharing All Influenza Data (GISAID) ${ }^{131}$ databases. A combination of viral RNA sequences was developed for the RT-PCR and used under the Food and Drug Administration (FDA). ${ }^{132}$ The most common sample used for detecting SARS-CoV-2 RNA is the upper respiratory tract (URT) or LRT specimens. ${ }^{133}$ CDC recommended swab samples of URT, especially the nasopharyngeal specimen, as the best option for the initial diagnosis of COVID-19. Sample collection must be done with adequate precautions to avoid accidental transmission of the disease. $^{80,134}$ 


\section{Types and Sites of Sample for RT-PCR}

There are various types of samples and sites that are used for COVID-19 testing as follows: ${ }^{80}$

\section{Nasopharyngeal (NP) Swab}

The NP swab is the most common sample recommended by the CDC. ${ }^{135}$ Other samples such as oropharyngeal (OP), nasal, and mid-turbinate swabs are used only when the NP swabs are not possible. ${ }^{133}$ The swabs to be used in sampling should be of synthetic fibre with a plastic shaft. Other types of swabs should be avoided because they may produce erroneous test results. ${ }^{133}$ For example, woodshafted swabs may affect the viral activity and the accuracy of RNA detection using PCR. The NP swab should be inserted deep into the nostrils and left in position for some time to allow thorough absorption of the secretion before extraction. ${ }^{133}$

\section{Oropharyngeal (OP) Swab}

The OP swab is commonly used as an alternative to the NP swab in COVID-19 testing. ${ }^{133}$ In cases when both the OP and NP swabs are taken, these swabs should be placed together in the same viral transport medium (VTM) transport tube to increase test sensitivity. The OP swab should be from the posterior pharynx and not the tongue. ${ }^{133}$ Currently, there were insufficient data to determine whether the OP or NP swab is more sensitive for detecting the SAR-CoV-2. ${ }^{136,137}$

\section{Nasal Mid-Turbinate (NMT) Swab or Anterior Nares Specimen}

The NMT is collected by health care professionals using a flocked-tapered and round foam swab and transported in a VTM container. ${ }^{133}$

\section{Nasopharyngeal Wash (Nasal Aspirate)}

A sterile container or a screw cap sputum collection cup is used to collect a few milliliters of aspirate. ${ }^{133}$

\section{Lower Respiratory Tract Aspirate (LRTA) Broncho-Alveolar Lavage (BAL) and Endotracheal Aspirate (EA)}

These sampling methods are among the most commonly used, especially in intubated patients under invasive ventilator treatment. ${ }^{133}$ LRTA, particularly BAL, by its high viral load, is more sensitive to the determination of COVID-19 than URT. ${ }^{80,134}$ In fact, COVID-19 tests on BAL and NP swab samples are more sensitive than those performed on the sputum or OP swab. ${ }^{80}$ NP would yield higher viral RNA yield than OP swabs.

\section{Sputum}

A sputum sample is only used in COVID-19 patients with productive coughs. The expectorated sample should be the deep cough sputum. The induction sputum production is not recommended in patients without a cough. ${ }^{133}$ Sputum was shown to be $72 \%$ positive for COVID-19, which second only to BAL in terms of PCR-positive results. ${ }^{80}$

\section{Blood}

Blood samples can be used in the diagnosis of COVID19. ${ }^{138}$ However, in a study on 205 COVID-19 patients, SARS-CoV-2-positive serum samples were detected in $1 \%$ of all cases, suggesting that blood tests are only helpful to determine when the disease has become systemic. ${ }^{80}$ PCRpositive results from serum samples of COVID-19 patients may only become evident by day 7 of infection. ${ }^{139}$ To examine that COVID-19 has become systemic, blood samples may be analyzed twice during acute and recovery stages. ${ }^{138}$

\section{Fecal and Anal Swabs}

COVID-19 can sometimes be detected in fecal ${ }^{140,141}$ and anal swabs. ${ }^{140}$ Currently, the frequency and duration of SARS-CoV-2 shedding in stool is unclear. ${ }^{138}$ For example, in blood, a stool sample may become positive for SARSCoV-2 only after 7 days of infection. ${ }^{139}$ It is shown that $29 \%$ of the fecal samples from COVID-19 patients were positive. ${ }^{80}$ Anal swabs may sometimes be positive for SARS-CoV-2, even when the oral swabs are negative. ${ }^{140}$

\section{Urine}

It is not clear as to the rate and duration of viral shedding in urine. ${ }^{138}$ In 72 confirmed COVID-19 cases, none of their urine samples were positive for SARS-CoV-2. ${ }^{80}$ Urine samples may be negative for the virus even when fecal samples show positive results. ${ }^{139}$

\section{Clustered Regularly Interspaced Short Palindromic Repeats (CRISPR)}

CRISPR is a rapid technique adapted for the detection of SARS-CoV-2. The method was first approved by USAFDA, in early 2020, as an alternative test for COVID-19 detection. ${ }^{142}$ The samples for the assay are similar to those used for RT-PCR. The assay, SARS-CoV-2 DETECTR, 
performs simultaneous recombinase polymerase amplification (RPA) and isothermal amplification using loopmediated amplification (LMA) from the extracted RNA, followed by Cas 12 detection. ${ }^{143}$ The benefit of the SARSCoV-2 DETECTR assay over RT-PCR for the detection of COVID-19 is that it has a higher limit of detection, shorter assay reaction time and lesser amount of assay sample and does not require bulky instruments. ${ }^{144}$

\section{Chest Imaging Chest X-Ray and Computed Tomography (CT)}

Both chest X-ray and CT scan were among the imaging techniques used to diagnose COVID-19 in the early stage of the disease when reliable test kits for microbial and molecular detection of the virus were not developed. ${ }^{145,146}$ However, the American College of Radiology did not recommend CT in the diagnosis of COVID-19 cases, claiming that the chest $\mathrm{CT}$ findings do not confirm COVID-19 or otherwise. ${ }^{147}$ However, several studies have shown that there is an association between CT findings and COVID-19. ${ }^{148-150}$ The sensitivity of chest CT chest was shown to be very high at $97 \%$. The chest CT characteristics in COVID-19 cases are identical to pneumonia, with ground glass appearance, mainly bilaterally, with or without consolidation. ${ }^{151,152}$ The abnormalities were mainly in the lower lobes, peripheral tissues, and posterior section of the lungs. ${ }^{150}$ Other less common CT findings in COVID-19 include pleural effusion and thickening, air bronchogram, and lymphadenopathy. ${ }^{146,148-150}$ The timing of the development of abnormal chest CT changes varies with the patient. In some patients, the CT changes precede symptoms and positive COVID-19 RTPCR test,${ }^{40,151}$ while in others, the changes develop after approximately 10 days of the symptoms. ${ }^{150}$ Chest CT may be abnormal in asymptomatic patients. ${ }^{153}$ In COVID-19, RT-PCR analysis may remain negative until late into the infection. In suspected COVID-19 cases, the CT findings show features characteristic of viral pneumonia, ${ }^{40,146}$ while RT-PCR tests remain negative. ${ }^{154}$

Computed tomography pulmonary angiogram (CTPA) has limited usefulness but is still used in patients with severe COVID-19. ${ }^{155}$ The scan is indicated in individuals with SARS-CoV-2 pneumonia, markedly elevated blood D-dimer values, and showing refractory or rapidly deteriorating hypoxemic respiratory failure. ${ }^{156}$

\section{Lung Ultrasound}

Lung ultrasound has been used as an alternative to chest X-Ray and CT to detect cases of COVID-19 pneumonia. ${ }^{157}$ The lung ultrasound is easier, more economical, and safer than X-ray or CT for patients and health professionals. The technique can be used in suspected COVID-19 cases with negative RT-PCR tests or confirmed COVID-19 cases during management and follow-up. ${ }^{158,159}$ The ultrasonograph in COVID-19 cases may show bilateral abnormalities, including an irregular pleural line with small pleural consolidations, areas of the white lung, and thick, confluent and irregular B-lines. ${ }^{157}$

\section{Laboratory Findings}

Table 2 lists some of the reported changes in hematological and serum biochemical parameters in COVID-19 patients. The most common findings or abnormalities in the blood of COVID-19 patients are neutrophilia with lymphopenia. ${ }^{160}$ These parameters may be used to determine the disease's severity and review the consequences of the treatment regimen. ${ }^{161}$

\section{Serological Test}

The RT-PCR tests for the diagnosis of COVID-19 have several limitations, including the high occurrence of falsenegative results. Serological tests are more rapid than the RT-PCR tests, allowing for earlier detection of the COVID-19 cases. ${ }^{162}$ The serological tests, based on the detection of serum antibody to SARS-CoV-2, are mainly performed on suspected COVID-19 patients showing symptoms consistent with COVID-19 but with negative RT-PCR test results. ${ }^{133,135}$ In this regard, in a small-scale survey in China, serological tests have shown that suspected COVID-19 cases with negative RT-PCR tests and without symptoms showed positive serum anti-SAR-CoV$2 \mathrm{IgG}$ and/or IgM levels, which highlights the importance of serological testing to achieve more accurate estimates of the extent of the COVID-19 pandemic. ${ }^{163}$ However, serological tests are plagued with cross-reactivity among coronaviruses. ${ }^{164}$

A point-of-care lateral flow immunoassay had shown promise with the capacity to simultaneously detect antiSARS-CoV-2 IgG and IgM antibodies within 15 minutes.162 The tests showed high sensitivity and specificity and can determine the rate and extent of an outbreak retrospectively. 
Table 2 Hematological and Serum Biochemical Changes in COVID-19 Patients

\begin{tabular}{|c|c|c|}
\hline Parameter & Pattern & Reference \\
\hline \multirow[t]{5}{*}{ Leukocyte (WBC) } & Normal & [189] \\
\hline & Leukopenia & {$[185]$} \\
\hline & Leukocytosis & {$[185]$} \\
\hline & Neutrophilia & [195] \\
\hline & Lymphopaenia & [195] \\
\hline Thrombocyte & Thrombocytopenia & [189] \\
\hline \multirow[t]{14}{*}{ Serum biochemistry } & Elevated C-reactive protein (CRP) & {$[1,203]$} \\
\hline & Decreased ferritin & [248] \\
\hline & Elevated Lactate dehydrogenase (LDH) & {$[181]$} \\
\hline & Elevated alanine transaminase (ALT) & {$[161]$} \\
\hline & Elevated aspartate transaminase (AST) & [161] \\
\hline & Elevate alkaline phosphatase (ALP) & [161] \\
\hline & Elevated amylase & [89] \\
\hline & Elevated creatine kinase & {$[161]$} \\
\hline & Elevated blood urea nitrogen (BUN) & {$[1]$} \\
\hline & Elevated creatinine & {$[1]$} \\
\hline & Mostly normal procalcitonin & [203] \\
\hline & Hyperfibrinogenemia & {$[161]$} \\
\hline & Elevated D-dimer & {$[156]$} \\
\hline & Decreased D-dimer & [249] \\
\hline
\end{tabular}

\section{Viral Sequencing}

In June 2020, the US FDA issued an emergency use authorization for next-generation sequencing in diagnosing COVID-19. The technique also allows for determining mutations in the SARS-CoV-2, which is crucial in the fight against the infection. ${ }^{165}$

\section{Viral Culture}

Viral cultures are beneficial for the isolation and characterization of the virus. However, for biosafety reasons, viral cultures are not recommended for the diagnosing of COVID-19. ${ }^{166}$

\section{Testing for Other Pathogens}

Other respiratory pathogens besides SARS-CoV-2 may present similar symptoms as COVID-19. Co-infections can also complicate the diagnosis of COVID-19. ${ }^{167,168}$ Among the most common co-infecting pathogens, especially in the frail elderly COVID-19 patients include Staphylococcus aureus, Klebsiella pneumoniae, and human herpes virus. ${ }^{169}$

\section{Differential Diagnosis}

COVID-19 has many clinical and radiological characteristics of pneumonia. Thus, it is imperative that during diagnosis, first rule out other respiratory viral infections that mimic COVID-19. ${ }^{97}$ A rapid molecular assay to differentially diagnose COVID-19 has been developed. ${ }^{170}$ The assay, QIAStat-Dx respiratory panel (QIAGEN, Milan, Italy) ${ }^{171}$ can detect several pathogens such as adenovirus, bocavirus, 4 other types of coronaviruses, influenza, para-influenza viruses, human metapneumovirus, Bordetella pertussis, and other pneumonia-causing pathogens. $^{170}$

\section{Co- and Superinfections}

The CDC suggested that when patients present with acute respiratory symptoms, clinicians should consider a differential diagnosis of COVID-19, influenza, and coinfections. ${ }^{172}$ Co-infections are uncommon at diagnosis in COVID-19 patients. ${ }^{173}$ However, it was reported that $50 \%$ of non-surviving COVID-19 patients were coinfected with bacteria including Streptococcus pneumoniae, Staphylococcus aureus, Klebsiella pneumoniae, Mycoplasma pneumoniae, Chlamydia pneumonia, Legionella pneumophila and Acinetobacter baumannii; Candida species and Aspergillus flavus; and viruses such as influenza, coronavirus, rhinovirus/enterovirus, parainfluenza, metapneumovirus, influenza B virus, and human immunodeficiency virus. ${ }^{174}$ 
Superinfection in COVID-19 is associated with severe illness that may lead to poor outcomes due to circulatory and multiple organ failures. ${ }^{97}$ Among the most common causes of superinfections in COVID-19 are Acinetobacter baumannii, Staphylococcus aureus and Aspergillus fumigatus. ${ }^{175,176}$

\section{COVID-19 Mimics and Chameleons}

Some patients suspected of COVID-19 may not present signs and symptoms typical of the disease. In one report, a COVID-19 patient twice tested negative for SARS-CoV-2 showed dyspnoea, coughs, and diffuse lung infiltrates first diagnosed to suffer from decompensated heart failure. This is an example of a "COVID-19 mimic". Some severe cases of COVID-19 may be asymptomatic or presented with non-specific signs of weakness and fatigue, and this is an example of "COVID-19 chameleon". These phenomena are common occurrences in COVID-19. ${ }^{177}$

\section{Treatment}

\section{Antiviral Therapy}

Although there are several compounds under development, there is no drug that is proven effective for treating COVID-19. ${ }^{1,178,179}$ Currently, the treatment for COVID19 is mainly supportive. There are, however, some encouraging results from the use of certain broad-spectrum antiviral drugs like nucleoside analogues and HIV-protease inhibitors that could attenuate viral infections. ${ }^{180}$

\section{Lopinavir/Ritonavir (LPV/r)}

In a hospital in Wuhan, China, treatment with LPV/r produced minimal clinical improvement or decreased the frequency of respiratory distress in COVID-19 patients. ${ }^{181,182}$ However, LPV/r treatment might help shorten the duration of viral shedding. ${ }^{183}$ Patients treated with LPV/r showed unwanted side effects such as gastrointestinal symptoms. ${ }^{182}$ Thus, further clinical trials are needed to evaluate LPV/r's efficacy in treatment. ${ }^{184}$

\section{Interferon Alpha (IFN- $\alpha$ )}

IFN- $\alpha$ nebulizations and sprays are used in COVID-19 treatment. ${ }^{185}$ IFN- $\alpha 2 b$, when used in combination with other antiviral drugs, has been shown to contribute to complete recovery for COVID-19. ${ }^{186,187}$ Subcutaneous injection of IFN- $\alpha 2 \mathrm{~b}$ combined with LPV/r shortened the length of hospitalization and accelerated viral clearance in COVID-19 patients. ${ }^{187}$ However, the IFN- $\alpha 2 b$ treatment must be applied with precautions because overdoses can cause myelosuppression and affect the liver and renal functions.

\section{Remdesivir}

Remdesivir is a nucleotide analogue broad-spectrum antiviral agent. An early study showed that remdesivir was effective in shortening the recovery time in adults hospitalized with COVID-19. ${ }^{188,189}$ However, human clinical trials have shown that the drug is ineffective, fails to prevent death in severe COVID-19 patients, and has side effects. ${ }^{190}$ Subsequently, the WHO issued a recommendation against the use of remdesivir in hospitalized COVID-19 patients, citing that there is no clear evidence on the effectiveness of the drug in improving the outcome of these patients. ${ }^{191}$ However, a very recent study showed that remdesivir is more effective and safer than standard care of treatment for the COVID-19 because it is associated with faster time to clinical improvement, reduction in mortality rate, and fewer incidence of serious adverse events. ${ }^{192}$

\section{Ribavirin}

Ribavirin is a guanosine analogue antiviral compound that has been used to treat infections caused by respiratory syncytial and hepatitis $\mathrm{C}$ viruses and viral hemorrhagic fever. However, there is no clear evidence that Ribavirin is beneficial in the treatment of COVID-19. Ribavirin reduces hemoglobin concentrations, an undesirable side effect in patients with respiratory disorders, compromising its potential as an antiviral against COVID-19. ${ }^{193}$

\section{Chloroquine and Hydroxychloroquine}

There are conflicting reports regarding the efficacy of chloroquine and hydroxychloroquine in the treatment of COVID-19. In vitro studies have shown that chloroquine is effective in inhibiting COVID-19 viral replication. Chloroquine or hydroxychloroquine block viral infections by interfering with the glycosylation of cellular receptors for the virus. ${ }^{194}$ The mechanism of action of chloroquine and hydroxychloroquine on SARS-CoV-19 are the same; however, hydroxyl-chloroquine may be more effective than chloroquine in reducing viral load. ${ }^{195}$ The antiviral effect of hydroxychloroquine is reinforced by the use of azithromycin. ${ }^{196}$

\section{Arbidol}

Arbidol is a potent broad-spectrum antiviral agent with activity against enveloped and non-enveloped viruses. Arbidol exerts its antiviral effect by blocking viral fusion with cells and inhibiting viral entry. ${ }^{197}$ Arbidol is used in 
the treatment of COVID-19 with variable results. In fact, Arbidol is shown to be superior to LPV/r in the treatment of COVID-19. ${ }^{198}$

\section{Favipiravir}

Favipiravir is an RNA-dependent RNA polymerase (RdRp) inhibitor. The favipiravir derivative, ribofuranosyl triphosphate, targets the influenza RdRP. ${ }^{199}$ In moderately severe, nonventilated COVID-19 patients, Favipiravir improved time to clinical recovery and decreased mortality rate. $^{200}$

\section{Glucocorticoids}

Early use of low-dose corticosteroids, especially dexamethasone, prednisone, and methylprednisolone, for a short duration was found to be useful in improving symptoms of COVID-19. ${ }^{201,202}$ However, there is no published evidence that corticosteroid treatment is effective against this disease. Corticosteroids have immunosuppressive properties and are thus not recommended for use to treat COVID-19 unless indicated. ${ }^{203}$

\section{Immunoglobulin and Hyper- Immune Serum}

Serum antibodies are effective against MERS and SARS coronavirus infections. Immunoglobulins have the advantage of providing protection against common infections, large donor pool, and commercial availability, while hyper-immune serums provide targeted immunity. ${ }^{204}$

\section{Teicoplanin}

Teicoplanin, a glycopeptide antibiotic routinely used to treat bacterial infections, was found to produce in vitro anti-SARS-CoV- 1 effect. The compound is among a list of alternative or complementary molecules used as therapeutic agents for COVID-19. ${ }^{205}$ Teicoplanin inhibits cleavage of viral spike protein by cathepsin L at the late stage of viral life cycles, thus, preventing the release of viral genomic RNA and curbing viral replication. ${ }^{206}$ The drug appears to have similar effects on SAR-CoV-2, making it a potential compound in the treatment of COVID-19. ${ }^{207}$

\section{Heparin}

COVID-19 patients at high risk of thromboembolic disease. ${ }^{208}$ The hypercoagulability state associated with the disease requires additional therapeutic interventions like the use of heparin. ${ }^{209}$ However, the use of prophylactic heparin in COVID-19 is still contentious. ${ }^{210}$ There are other anticoagulants and antiplatelet agents that can be used as alternatives to address the hypercoagulability state in COVID-19. ${ }^{211}$

\section{Aspirin}

Aspirin, an anti-inflammatory and antiplatelet agent, can prevent the development of a hypercoagulability state and reduce the risk of thromboembolic incidence in COVID19 patients. $^{212}$ The drug also reduces the risk of death in patients with severe COVID-19. ${ }^{213,214}$

\section{Ivermectin}

Ivermectin is an oral anthelmintic that is used to paralyze and kill gastrointestinal parasites. Recently, ivermectin was shown to inhibit SARS-CoV-2 replication in vitro. ${ }^{215}$ The drug inhibits viral replication by inhibiting viral protein movement within the cell. Based on the in vitro data, the equivalent dose required to produce antiviral effects in the human body exceeds the recommended therapeutic dose, thus, not practical for human use. ${ }^{216}$ However, very recently, a meta-analysis of randomized clinical trial studies suggests that ivermectin may offer beneficial effects towards COVID-19 outcomes. ${ }^{217}$

\section{Inflammatory Cytokine Inhibitors}

Inflammatory cytokine storm is a common manifestation in COVID-19. In severely ill patients, the concentration of pro-inflammatory cytokines, such as IL-6, tended to be high. High cytokine levels indicate a poor prognosis in COVID-19. ${ }^{218}$ Thus, among the complementary therapeutic approaches in COVID-19 is the management of the inflammatory responses. Among the anti-inflammatory drugs shown to reduce the risk of hospitalization in COVID-19 patients are colchicine, ${ }^{219}$ prostaglandins nonsteroidal and anti-inflammatory drugs, ${ }^{220}$ except ibuprofen. ${ }^{221}$ Carprofen, a human and celecoxib, a veterinary anti-inflammatory drug, also inhibited a crucial enzyme in the replication and transcription of SARSCoV-2.

\section{Respiratory Support}

The most critical support for patients with respiratory distress and/or hypoxemia is oxygenation. Convention oxygen therapy may not be sufficient in adults COVID- 
19 patients with acute hypoxemic respiratory failure. In these patients, depending on severity, oxygenation may be supplied either by high-flow nasal cannula, endotracheal intubation, or invasive mechanical ventilation. The target for optimal oxygen saturation in adults with COVID-19 is $92 \%$ to $96 \%$. In cases of severe lung failure, extracorporeal membrane oxygenation (ECMO) is used to re-establish pulmonary gas exchange. ${ }^{222}$ The estimated mortality in patients with severe COVID-19 who received ECMO is $<40 \%{ }^{223}$

\section{Circulatory Support}

Severe COVID-19 is associated with circulatory and cardiac involvement, which can be fatal. ${ }^{24,225}$ Venovenous extracorporeal membrane oxygenation (VV-ECMO) support is often instituted in patients with COVID-19-related acute hypoxaemic respiratory failure. This treatment is only appropriate in patients with cardiac disease. In COVID-19 patients with heart failure and decreased cardiac output, it is necessary to institute extracorporeal life support (ECLS). ${ }^{222}$

\section{Blood Purification Treatment}

Blood purification treatment comprising plasma exchange, perfusion, absorption, and blood/plasma filtration ${ }^{226}$ can be applied during the cytokine storm at the early and middle stages of COVID-19. The treatment removes inflammatory factors that could potentially cause damage and death to severely ill COVID-19 patients. ${ }^{227}$

\section{Biologicals}

Tocilizumab is a humanized monoclonal antibody against the IL-6 receptor. IL-6, a pro-inflammatory cytokine implicated in the pathogenesis of many diseases. Although recommended for use in COVID-19 patients to reduce lung tissue inflammation, ${ }^{228}$ tocilizumab did not appear to be effective in preventing death in moderately ill hospitalization patients. ${ }^{229}$ However, a very recent meta-analysis study showed that tocilizumab treatment is associated with a reduction of mortality rate from COVID-19 but did not alter the severity of the disease and length of hospital stay; thus, it does not support the routine use of tocilizumab for COVID-19 patients. ${ }^{230}$

\section{Convalescent Plasma}

The COVID-19 convalescent plasma (CP) is a source of anti-SARS-CoV-2 antibodies. It can potentially induce passive immunization in the COVID-19 patients ${ }^{231}$ to improve viral clearance and destroy virus-infected cells through cell-mediated cytotoxicity. ${ }^{232} \mathrm{CP}$ treatment may be used in hospitalized patients with rapid disease progression. ${ }^{233}$ The treatment was shown to increase lymphocyte counts, inflammation markers, and enzymes of inflammation like C-reactive protein (CRP), alanine aminotransferase (ALT) and aspartate aminotransferase (AST). However, CP treatment did not reduce the progression of COVID-19 while showing potential for adverse transfusion events, circulatory overload, and anaphylaxis. ${ }^{234}$

\section{Vaccine}

Six efficacious vaccines for COVID-19, by Pfizer Inc. and BioNTech SE, Moderna, Oxford-AstraZeneca, Gamaleya Research Institute, Sinopharm, and Sinovac are now available.

\section{BNTI $62 b 2$}

The Pfizer-BioNTech BNT162b2 (generic name tozinameran, brand name Comirnaty) mRNA vaccine encapsulated in lipid nanoparticles with an efficacy rate of $95 \%$ requires refrigeration at $-70^{\circ} \mathrm{C}$ for transportation.

\section{mRNA- 1273}

The Moderna vaccine, mRNA-1273, is also an mRNA vaccine encapsulated in lipid nanoparticles. The mRNA1273 has an efficacy rate of $94.1 \%$ and is stable for 6 months while requiring less stringent transportation conditions at $-20^{\circ} \mathrm{C}$ than BNT162b2. ${ }^{235}$

\section{AZDI222 (ChAdOxI nCoV-I9)}

The Oxford-AstraZeneca AZD1222 vaccine, also known as ChAdOx1 $\mathrm{nCoV}-19$ vaccine, uses a vector, the modified chimpanzee adenovirus ChAdOx1. The AZD1222 is stable below the average refrigerator temperature. ${ }^{190}$

\section{Gam-COVID-Vac}

The Gamaleya Research Institute of Epidemiology and Microbiology, Russia, developed the Gam-COVID-Vac, trade-name Sputnik $\mathrm{V}$, primarily approved for use in Russia. $^{236}$ Sputnik V is a viral two-vector vaccine based on two human common cold adenoviruses formulated as frozen (storage temperature $-18^{\circ} \mathrm{C}$ ) and freeze-dried (storage temperature $2-8^{\circ} \mathrm{C}$ ) dosage forms. ${ }^{237,238}$ 


\section{BBIPI-Cor-V and BBIBP-Cor-V}

The Chinese Sinopharm BBIBP-Cor-V and Sinovac CoronaVac vaccines are conventional inactivated vaccines. The efficacy of BBIBP-Cor-V is $79.34 \%$. Based on the Turkish clinical trial, the efficacy rate of the CoronaVac vaccine is $91.25 \%$. Both the BBIBPI-Cor-V and CoronaVac vaccine can be transported and refrigerated at $2-8^{\circ} \mathrm{C} .{ }^{190}$

\section{Supportive Care}

\section{Vitamin D}

Several dietary supplements and drugs have been recommended to enhance immunity and reduce the risk of acquiring COVID-19. ${ }^{239}$ Vitamin D is recommended for COVID-19 patients because the level of this vitamin is markedly low in severe COVID-19 patients, while vitamin D-deficient patients show high inflammatory responses. ${ }^{240}$ Vitamin D as an anti-inflammatory supplement offers beneficial effects ${ }^{241}$ that suppresses viral replication, reduces the development of pneumonia, ${ }^{242}$ and reduces mortality in COVID-19. ${ }^{243}$

\section{Vitamin C}

Vitamin C (ascorbic acid) is a water-soluble vitamin that is believed to have beneficial effects in patients with severe and critical illnesses. ${ }^{244}$ Vitamin C plays a role in the prevention and treatment of viral infections by scavenging free oxygen radicals, reducing the accumulation of pro-inflammatory cytokines, and enhancing antimicrobial ability. ${ }^{245,246}$ There is insufficient data to consider vitamin $\mathrm{C}$ as a complementary treatment for COVID-19. ${ }^{244}$ However, vitamin C is suggested to be administered to severe cases of COVID-19 because of its safety profile, low cost, and potential for rapid upscaling of production. ${ }^{247,248}$ In this regard, Hiedra et al in the USA found a significant decrease in inflammatory markers (ferritin and D-dimer) and a trend to decrease FiO2 requirements after intravenous vitamin $\mathrm{C}$ administration in seventeen COVID-19 patients. $^{249}$

\section{Zinc}

The trace mineral zinc is hypothesized to prevent viral attachment to the nasopharyngeal mucosa and inhibit viral replication. One study showed that zinc inhibits RNA polymerase and plays a central role against coronavirus infections. ${ }^{250}$ Zinc is essential in preserving tissue barriers, such as the respiratory epithelium that prevents entry of pathogens into cells, the immune and redox system and prevents progression of COVID-19. ${ }^{206}$

\section{Famotidine}

Famotidine is a histamine-2 receptor antagonist (H2RA) that is used to prevent gastrointestinal ulceration. H2RA was found to inhibit HIV replication. ${ }^{251}$ Thus, the drug was suggested as an optional prophylactic medication in COVID-19. In a recent retrospective study, among hospitalized COVID-19 patients, the use of famotidine was linked to the reduction in disease deterioration. ${ }^{252}$ This may suggest that the effect of H2RA is beyond anti-acid activity but also has a potential complementary drug in COVID-19 since it improves clinical outcomes in nonhospitalized patients. ${ }^{253}$

\section{Conclusion}

Although some drugs are being investigated, there is currently no effective treatment for COVID-19. Fortunately, several newly developed vaccines have proven to be highly efficacious for the disease. However, until sufficient herd immunity is achieved in the population, precautions, such as wearing masks, avoiding crowds, social distancing, and regular washing of hands, are still imperative to prevent the further spread of the disease.

There are many risk factors associated with COVID19 infection and its severity, including age, sex, sociodemographic behavior, comorbidities, and the psychological condition of the patient. Older adults and healthcare workers are particularly susceptible to the COVID-19. For that reason, these people were among the first groups scheduled to receive the vaccine. Although COVID-19 is primarily a pulmonary disease, it is also associated with cardiac, dermatologic, haematological, hepatic, neurological, and renal complications. The critically COVID-19 patients are particularly at high risk for thromboembolic events. Although the immediate clinical manifestations of the COVID-19 are generally clear, the long-term effect of the disease is still unknown. The role of vertical transmission in neonates and the incidence of COVID-19 in children is not clear. However, immunocompromised children and those with underlying cardiovascular disorders are at risk of acquiring the severe disease.

The emergence of a new strain of SARS-CoV-2 is causing concern. The new strain appears to spread quickly but does not seem to cause anymore severe COVID-19. The current vaccines appeared to be efficacious in the 
prevention of infection by the new SARS-CoV-2 strain. However, the data are still preliminary, and the long-term effect of disease by the new SARS-CoV-2 strain is still unknown.

\section{Disclosure}

The authors declare no conflicts of interest related to this work/review article.

\section{References}

1. Lai -C-C, Liu YH, Wang C-Y, et al. Asymptomatic carrier state, acute respiratory disease, and pneumonia due to severe acute respiratory syndrome coronavirus 2 (SARSCoV-2): facts and myths. $J$ Microbiol Immunol Infect. 2020;53(3):404-412. doi:10.1016/j.jmii.2020.02.012

2. Singhal T. A review of coronavirus disease-2019 (COVID-19). Indian J Pediatr. 2020;87(4):281-286. doi:10.1007/s12098-020-03263-6

3. Heneghan C, Brassey J, Jefferson T. COVID-19: what proportion are asymptomatic? The Centre for Evidence-Based Medicine; 2020. Available from: https://www.cebm.net/covid-19/covid-19what-proportion-are-asymptomatic/. Accessed November 30, 2021.

4. Gautret P, Lagier J-C, Parola P, et al. Hydroxychloroquine and azithromycin as a treatment of COVID-19: results of an openlabel non-randomized clinical trial. Int $J$ Antimicrob Agents. 2020;56(1):105949. doi:10.1016/j.ijantimicag.2020.105949

5. Tian X, Li C, Huang A, et al. Potent binding of 2019 novel coronavirus spike protein by a SARS coronavirus-specific human monoclonal antibody. Emerg Microbes Infect. 2020;9 (1):382-385. doi:10.1080/22221751.2020.1729069

6. Chan JF-W, Kok K-H, Zhu Z, et al. Genomic characterization of the 2019 novel human-pathogenic coronavirus isolated from a patient with atypical pneumonia after visiting Wuhan. Emerg Microbes Infect. 2020;9(1):221-236. doi:10.1080/22221751.2020.1719902

7. Li W, Shi Z, Yu M, et al. Bats are natural reservoirs of SARS-like coronaviruses. Science. 2005;310(5748):676-679. doi:10.1126/ science. 1118391

8. Zhang T, Wu Q, Zhang Z. Probable pangolin origin of SARSCoV-2 associated with the COVID-19 outbreak. Curr Biol. 2020;30(8):1578. doi:10.1016/j.cub.2020.03.063

9. Hoffmann M, Kleine-Weber H, Schroeder S, et al. SARS-CoV-2 cell entry depends on ACE2 and TMPRSS2 and is blocked by a clinically proven protease inhibitor. Cell. 2020;181(2):271-280. e8. doi:10.1016/j.cell.2020.02.052

10. Uzoigwe CE. Body temperature and host species preferences of SARS-CoV-2. Clin Microbiol Infect. 2020;26(12):1709-1710. doi:10.1016/j.cmi.2020.07.017

11. Guo Y-R, Cao Q-D, Hong Z-S, et al. The origin, transmission and clinical therapies on coronavirus disease 2019 (COVID-19) outbreak-an update on the status. Mil Med Res. 2020;7(1):1-10. doi:10.1186/s40779-020-00240-0

12. Letko M, Marzi A, Munster V. Functional assessment of cell entry and receptor usage for SARS-CoV-2 and other lineage B betacoronaviruses. Nat Microbiol. 2020;5(4):562-569. doi:10.1038/s41564-020-0688-y

13. Lauer SA, Grantz KH, Bi Q, et al. The incubation period of coronavirus disease 2019 (COVID-19) from publicly reported confirmed cases: estimation and application. Ann Intern Med. 2020;172(9):577-582. doi:10.7326/M20-0504
14. Pal M, Berhanu G, Desalegn C, Kandi V. Severe acute respiratory syndrome coronavirus-2 (SARS-CoV-2): an update. Cureus. 2020;12(3). doi:10.7759/cureus.7423

15. Chams N, Chams S, Badran R, et al. COVID-19: a multidisciplinary review. Front Public Health. 2020;8(383):1-20. doi:10.3389/fpubh.2020.00383

16. Wrapp D, Wang N, Corbett KS, et al. Cryo-EM structure of the $2019-\mathrm{nCoV}$ spike in the prefusion conformation. Science. 2020;367(6483):1260-1263. doi:10.1126/science.abb2507

17. Paules CI, Marston HD, Fauci AS. Coronavirus infections - more than just the common cold. JAMA. 2020;323(8):707-708. doi:10.1001/jama.2020.0757

18. Del Rio C, Malani PN. 2019 novel coronavirus - important information for clinicians. JAMA. 2020;323(11):1039-1040. doi:10.1001/jama.2020.1490

19. Kumar S, Maurya VK, Prasad AK, et al. Structural, glycosylation and antigenic variation between 2019 novel coronavirus (2019$\mathrm{nCoV}$ ) and SARS coronavirus (SARS-CoV). Virusdisease. 2020;31(1):13-21.

20. Chen Y, Liu Q, Guo D. Emerging coronaviruses: genome structure, replication, and pathogenesis. J Med Virol. 2020;92(4):418423. doi:10.1002/jmv.25681

21. Wu A, Peng Y, Huang B, et al. Genome composition and divergence of the novel coronavirus $(2019-\mathrm{nCoV})$ originating in China. Cell Host Microbe. 2020;27:325-328. doi:10.1016/j.chom.2020.02.001

22. Xu Z, Peng C, Shi Y, et al. Nelfinavir was predicted to be a potential inhibitor of 2019-nCov main protease by an integrative approach combining homology modelling, molecular docking and binding free energy calculation. BioRxiv. 2020. doi:10.1101/ 2020.05.09.086165

23. Santonja C, Heras F, Núñez L, Requena L. COVID-19 chilblainlike lesion: immunohistochemical demonstration of SARS-CoV-2 spike protein in blood vessel endothelium and sweat gland epithelium in a polymerase chain reaction-negative patient. $\mathrm{Br} J$ Dermatol. 2020;183(4):778-780. doi:10.1111/bjd.19338

24. Hui KP, Cheung M-C, Perera RA, et al. Tropism, replication competence, and innate immune responses of the coronavirus SARS-CoV-2 in human respiratory tract and conjunctiva: an analysis in ex-vivo and in-vitro cultures. Lancet Respir Med. 2020;8(7):687-695. doi:10.1016/S2213-2600(20)30193-4

25. Backer JA, Klinkenberg D, Wallinga J. Incubation period of 2019 novel coronavirus (2019-nCoV) infections among travellers from Wuhan, China, 20-28 January 2020. Eurosurveillance. 2020;25 (5):2000062. doi:10.2807/1560-7917.ES.2020.25.5.2000062

26. Varia M, Wilson S, Sarwal S, et al. Investigation of a nosocomial outbreak of severe acute respiratory syndrome (SARS) in Toronto, Canada. CMAJ. 2003;169(4):285-292.

27. Virlogeux V, Fang VJ, Park M, et al. Comparison of incubation period distribution of human infections with MERS-CoV in South Korea and Saudi Arabia. Sci Rep. 2016;6(1):1-7. doi:10.1038/srep35839

28. Wang W, Tang J, Wei F. Updated understanding of the outbreak of 2019 novel coronavirus (2019-nCoV) in Wuhan, China. J Med Virol. 2020;92(4):441-447. doi:10.1002/jmv.25689

29. Zhang J, Cao Y, Tan G, et al. Clinical, radiological, and laboratory characteristics and risk factors for severity and mortality of 289 hospitalized COVID-19 patients. Allergy. 2021;76(2):533550. doi:10.1111/all.14496

30. Tian $\mathrm{S}, \mathrm{Hu} \mathrm{N}$, Lou J, et al. Characteristics of COVID-19 infection in Beijing. $J$ Infect. 2020;80(4):401-406. doi:10.1016/j. jinf.2020.02.018

31. Wang $\mathrm{D}, \mathrm{Hu} \mathrm{B}, \mathrm{Hu} \mathrm{C}$, et al. Clinical characteristics of 138 hospitalized patients with 2019 novel coronavirus-infected pneumonia in Wuhan, China. JAMA. 2020;323(11):1061-1069. doi:10.1001/jama.2020.1585 
32. Alimohamadi Y, Sepandi M, Taghdir M, Hosamirudsari H. Determine the most common clinical symptoms in COVID-19 patients: a systematic review and meta-analysis. J Prev Med Hyg. 2020;61(3):E304. doi:10.15167/2421-4248/jpmh2020.61.3.1530

33. Grasselli G, Greco M, Zanella A, et al. Risk factors associated with mortality among patients with COVID-19 in intensive care units in Lombardy, Italy. JAMA Intern Med. 2020;180(10):1345. doi:10.1001/jamainternmed.2020.3539

34. Wollina U, Karadağ AS, Rowland-Payne C, et al. Cutaneous signs in COVID-19 patients: a review. Dermatol Ther. 2020;33 (5):e13549. doi:10.1111/dth.13549

35. Bernheim A, Mei $X$, Huang $M$, et al. Chest $C T$ findings in coronavirus disease-19 (COVID-19): relationship to duration of infection. Radiology. 2020;295(3):200463. doi:10.1148/ radiol.2020200463

36. Wong HYF, Lam HYS, Fong AH-T, et al. Frequency and distribution of chest radiographic findings in patients positive for COVID-19. Radiology. 2020;296(2):E72-E8. doi:10.1148/ radiol.2020201160

37. Fang Y, Zhang H, Xie J, et al. Sensitivity of chest CT for COVID19: comparison to RT-PCR. Radiology. 2020;296(2):E115-E7. doi:10.1148/radiol.2020200432

38. Zhang R, Tie X, Qi Z, et al. Diagnosis of covid-19 pneumonia using chest radiography: value of artificial intelligence. Radiology. 2021;298:E88-E97.

39. Lomoro P, Verde F, Zerboni F, et al. COVID-19 pneumonia manifestations at the admission on chest ultrasound, radiographs, and CT: single-center study and comprehensive radiologic literature review. Eur J Radiol Open. 2020:100231. doi:10.1016/j. ejro.2020.100231

40. Xie X, Zhong Z, Zhao W, et al. Chest CT for typical 2019-nCoV pneumonia: relationship to negative RT-PCR testing. Radiology. 2020;296:E41-E45.

41. Cao Q, Chen Y-C, Chen C-L, Chiu C-H. SARS-CoV-2 infection in children: transmission dynamics and clinical characteristics. $J$ Formos Med Assoc. 2020;119(3):670. doi:10.1016/j. jfma.2020.02.009

42. Su L, Ma X, Yu H, et al. The different clinical characteristics of corona virus disease cases between children and their families in China-the character of children with COVID-19. Emerg Microbes Infect. 2020;9(1):707-713. doi:10.1080/22221751.2020.1744483

43. Gruber CN, Patel RS, Trachtman R, et al. Mapping systemic inflammation and antibody responses in multisystem inflammatory syndrome in children (MIS-C). Cell. 2020;183(4):982-95. e14. doi:10.1016/j.cell.2020.09.034

44. Salih AF, Hamasalih K, Rahman HS, Mohammed GA. Pediatric COVID-19 infection in Sulaymaniyah Governorate, Iraq. $\mathrm{Am} J$ Otolaryngol. 2022;43(1):103199. doi:10.1016/j.amjoto.2021.103199

45. Hariyanto TI, Lugito NPH, Yanto TA, et al. Insulin therapy and outcome from coronavirus disease 2019 (COVID-19): a systematic review, meta-analysis, and meta-regression. Endocr Metab Immune Disord Drug Targets. 2021;21. doi:10.2174/ 1871530321666210709164925

46. Shi Y, Yu X, Zhao H, et al. Host susceptibility to severe COVID19 and establishment of a host risk score: findings of 487 cases outside Wuhan. Crit Care. 2020;24(1):1-4. doi:10.1186/s13054020-2833-7

47. Kopel J, Perisetti A, Roghani A, et al. Racial and gender-based differences in COVID-19. Front Public Health. 2020;8:418. doi:10.3389/fpubh.2020.00418

48. Jin J-M, Bai P, He W, et al. Gender differences in patients with COVID-19: focus on severity and mortality. Front Public Health. 2020;8:152. doi:10.3389/fpubh.2020.00152
49. Guan W-J, Liang W-H, Zhao Y, et al. Comorbidity and its impact on 1590 patients with Covid-19 in China: a Nationwide Analysis. Eur Respir J. 2020;55(5):2000547. doi:10.1183/13993003.005472020

50. Richardson S, Hirsch JS, Narasimhan M, et al. Presenting characteristics, comorbidities, and outcomes among 5700 patients hospitalized with COVID-19 in the New York City area. JAMA. 2020;323(20):2052. doi:10.1001/jama.2020.6775

51. Hariyanto TI, Putri C, Hananto JE, et al. Delirium is a good predictor for poor outcomes from coronavirus disease 2019 (COVID-19) pneumonia: a systematic review, meta-analysis, and meta-regression. $J$ Psychiatr Res. 2021;142:361-368. doi:10.1016/j.jpsychires.2021.08.031

52. Hariyanto TI, Putri C, Arisa J, et al. Dementia and outcomes from coronavirus disease 2019 (COVID-19) pneumonia: a systematic review and meta-analysis. Arch Gerontol Geriatr. 2020;93:104299. doi:10.1016/j.archger.2020.104299

53. Putri C, Hariyanto TI, Hananto JE, et al. Parkinson's disease may worsen outcomes from coronavirus disease 2019 (COVID-19) pneumonia in hospitalized patients: a systematic review, metaanalysis, and meta-regression. Parkinsonism Relat Disord. 2021;87:155-161. doi:10.1016/j.parkreldis.2021.04.019

54. Hariyanto TI, Kurniawan A. Obstructive sleep apnea (OSA) and outcomes from coronavirus disease 2019 (COVID-19) pneumonia: a systematic review and meta-analysis. Sleep Med. 2021;82 (4):47-53. doi:10.1016/j.sleep.2021.03.029

55. Hariyanto TI, Kurniawan A. Dipeptidyl peptidase 4 (DPP4) inhibitor and outcome from coronavirus disease 2019 (COVID-19) in diabetic patients: a systematic review, meta-analysis, and metaregression. J Diabetes Metab Disord. 2021;20:543-550.

56. Hariyanto TI, Intan D, Hananto JE, et al. Pre-admission glucagonlike peptide-1 receptor agonist (GLP-1RA) and mortality from coronavirus disease 2019 (Covid-19): a systematic review, metaanalysis, and meta-regression. Diabetes Res Clin Pract. 2021;179:109031. doi:10.1016/j.diabres.2021.109031

57. Hariyanto TI, Japar KV, Damay V, et al. The use of ACE inhibitor/ ARB in SARS-CoV-2 patients: a comprehensive narrative review. Asian J Med Sci. 2020;11(6):113-120. doi:10.3126/ajms.v11i6.29911

58. Zhao J, Yang Y, Huang H, et al. Relationship between the ABO Blood Group and the COVID-19 Susceptibility. medRxiv. 2020 [Preprint]. doi:10.1101/2020.03.11.20031096

59. Latz CA, DeCarlo C, Boitano L, et al. Blood type and outcomes in patients with COVID-19. Ann Hematol. 2020;99(9):21132118. doi:10.1007/s00277-020-04169-1

60. Franchini M, Cruciani M, Mengoli C, et al. ABO blood group and COVID-19: an updated systematic literature review and meta-analysis. Blood Transfus. 2021;19(4):317-326. doi:10.2450/2021.0049-21

61. Behboudi E, Hamidi V, Gholizadeh F, et al. Association between $\mathrm{ABO}$ blood groups and rhesus antigen and susceptibility to COVID-19 in the Yazd hospital. New Microbes New Infect. 2021;44:100934. doi:10.1016/j.nmni.2021.100934

62. Levi JE, Telles PR, Scrivani H, et al. Lack of association between $\mathrm{ABO}$ blood groups and susceptibility to SARS-CoV-2 infection. Hematol Transfus Cell Ther. 2020;42:541. doi:10.1016/j. htct.2020.10.914

63. Hariyanto TI, Kurniawan A. Anemia is associated with severe coronavirus disease 2019 (COVID-19) infection. Transfus Apher Sci. 2020;59(6):1-2. doi:10.1016/j.transci.2020.102926

64. Novelli EM, Huynh C, Gladwin MT, et al. Pulmonary embolism in sickle cell disease: a case-control study. J Thromb Haemost. 2012;10(5):760-766. doi:10.1111/j.1538-7836.2012.04697.x

65. Sonakul D, Fucharoen S. Pulmonary thromboembolism in thalassemic patients. Southeast Asian J Trop Med Public Health. 1992;23:25-28. 
66. Grillet F, Behr J, Calame P, et al. Acute pulmonary embolism associated with COVID-19 pneumonia detected by pulmonary CT angiography. Radiology. 2020;296:E186-E188.

67. Lin W, Wen J, Chen G. Epidemiological and clinical characteristics of SARS-CoV-2 and SARS-CoV: a system review. medRxiv. 2020. doi:10.1101/2020.07.12.20151068

68. Liu W, Wang Q, Zhang Q, et al. Coronavirus disease 2019 (COVID-19) during pregnancy: a case series; 2020.

69. Patel R, Babady E, Theel ES, et al. Report from the American Society for Microbiology COVID-19 international summit, 23 march 2020: value of diagnostic testing for SARS-CoV-2/COVID19. Am Soc Microbiol. 2020. doi:10.1128/mBio.00722-20

70. World Health Organization. WHO Director-General's opening remarks at the media briefing on COVID-19-11 March 2020 Geneva, Switzerland; 2020.

71. Carsana L, Sonzogni A, Nasr A, et al. Pulmonary post-mortem findings in a series of COVID-19 cases from northern Italy: a two-centre descriptive study. Lancet Infect Dis. 2020;20 (10):1135-1140. doi:10.1016/S1473-3099(20)30434-5

72. Garfin DR, Silver RC, Holman EA. The novel coronavirus (COVID-2019) outbreak: amplification of public health consequences by media exposure. Health Psychol. 2020;39(5):355357. doi: $10.1037 /$ hea0000875

73. McIntosh K, Hirsch M, Bloom A. COVID-19: epidemiology, virology, and prevention. UpToDate; 2021. Available from: https://www.uptodate.com/contents/covid-19-epidemiology-virol ogy-and-prevention. Accessed March 18, 2021.

74. Singh SP, Pritam M, Pandey B, Yadav TP. Microstructure, pathophysiology, and potential therapeutics of COVID-19: a comprehensive review. J Med Virol. 2021;93(1):275-299. doi:10.1002/ jmv. 26254

75. Gupta A, Madhavan MV, Sehgal K, et al. Extrapulmonary manifestations of COVID-19. Nat Med. 2020;26(7):1017-1032. doi:10.1038/s41591-020-0968-3

76. Yuki K, Fujiogi M, Koutsogiannaki S. COVID-19 pathophysiology: a review. Clin Immunol. 2020;215:108427. doi:10.1016/j. clim.2020.108427

77. Huang C, Wang Y, Li X, et al. Clinical features of patients infected with 2019 novel coronavirus in Wuhan, China. Lancet. 2020;395(10223):497-506. doi:10.1016/S0140-6736(20)30183-5

78. Tang $\mathrm{X}, \mathrm{Wu} \mathrm{C}, \mathrm{Li} \mathrm{X}$, et al. On the origin and continuing evolution of SARS-CoV-2. Natl Sci Rev. 2020;7(6):1012-1023. doi:10.1093/nsr/nwaa036

79. Lau SK, Li KS, Huang Y, et al. Ecoepidemiology and complete genome comparison of different strains of severe acute respiratory syndrome-related Rhinolophus bat coronavirus in China reveal bats as a reservoir for acute, self-limiting infection that allows recombination events. $J$ Virol. 2010;84(6):2808-2819. doi:10.1128/JVI.02219-09

80. Wang W, Xu Y, Gao R, et al. Detection of SARS-CoV-2 in different types of clinical specimens. JAMA. 2020;323 (18):1843-1844. doi:10.1001/jama.2020.3786

81. Wong MC, Cregeen SJJ, Ajami NJ, Petrosino JF. Evidence of recombination in coronaviruses implicating pangolin origins of nCoV-2019. Biorxiv. 2020. doi:10.1101/2020.02.07.939207

82. Xiao K, Zhai J, Feng Y, et al. Isolation and characterization of 2019-nCoV-like coronavirus from Malayan pangolins. BioRxiv. 2020. doi:10.1101/2020.02.17.951335

83. Lam TTY, Jia N, Zhang YW, et al. Identifying SARS-CoV-2related coronaviruses in Malayan pangolins. Nature. 2020;583 (7815):282-285. doi:10.1038/s41586-020-2169-0

84. Jin X, Lian J-S, Hu J-H, et al. Epidemiological, clinical and virological characteristics of 74 cases of coronavirus-infected disease 2019 (COVID-19) with gastrointestinal symptoms. Gut. 2020;69(6):1002-1009. doi:10.1136/gutjnl-2020-320926
85. Jalava K. First respiratory transmitted food borne outbreak? Int $J$ Hyg Environ Health. 2020;226:113490. doi:10.1016/j. ijheh.2020.113490

86. She J, Jiang J, Ye L, et al. 2019 novel coronavirus of pneumonia in Wuhan, China: emerging attack and management strategies. Clin Transl Med. 2020;9(1):1-7. doi:10.1186/s40169-020-00271-z

87. Boldog P, Tekeli T, Vizi Z, et al. Risk assessment of novel coronavirus COVID-19 outbreaks outside China. J Clin Med. 2020;9(2):571. doi:10.3390/jcm9020571

88. Rothe C, Schunk M, Sothmann P, et al. Transmission of 2019$\mathrm{nCoV}$ infection from an asymptomatic contact in Germany. $N$ Engl J Med. 2020;382(10):970-971. doi:10.1056/NEJMc2001468

89. Zhou C. Evaluating new evidence in the early dynamics of the novel coronavirus COVID-19 outbreak in Wuhan, China with real time domestic traffic and potential asymptomatic transmissions. medRxiv. 2020. doi:10.1101/2020.02.15.20023440

90. Hu Z, Song C, Xu C, et al. Clinical characteristics of 24 asymptomatic infections with COVID-19 screened among close contacts in Nanjing, China. Sci China Life Sci. 2020:1-6. doi:10.2139/ssrn.3543598

91. Lu Q, Shi Y. Coronavirus disease (COVID-19) and neonate: what neonatologist need to know. J Med Virol. 2020;92(6):564-567. doi:10.1002/jmv.25740

92. Belser JA, Rota PA, Tumpey TM. Ocular tropism of respiratory viruses. Microbiol Mol Biol Rev. 2013;77(1):144-156. doi:10.1128/MMBR.00058-12

93. Koenig KL, Bey CK, McDonald EC. 2019-nCoV: the identifyisolate-inform (3I) tool applied to a novel emerging coronavirus. West J Emerg Med. 2020;21(2):184. doi:10.5811/ westjem.2020.1.46760

94. Urrutia-Pereira M, Mello-da-silva CA, Solé D. Household pollution and COVID-19: irrelevant association? Allergol Immunopathol. 2021;49(1):146-149. doi:10.15586/aei.v49i1.48

95. Wong J, Goh QY, Tan Z, et al. Preparing for a COVID-19 pandemic: a review of operating room outbreak response measures in a large tertiary hospital in Singapore. Can J Anesth. 2020;67(6):732-745.

96. Peng X, Xu X, Li Y, et al. Transmission routes of 2019-nCoV and controls in dental practice. Int J Oral Sci. 2020;12(1):1-6. doi:10.1038/s41368-020-0075-9

97. Bouadma L, Lescure F-X, Lucet J-C, et al. Severe SARS-CoV-2 infections: practical considerations and management strategy for intensivists. Intensive Care Med. 2020;46(4):579-582.

98. Yeo C, Kaushal S, Yeo D. Enteric involvement of coronaviruses: is faecal-oral transmission of SARS-CoV-2 possible? Lancet Gastroenterol Hepatol. 2020;5(4):335-337. doi:10.1016/S24681253(20)30048-0

99. van Doremalen N, Bushmaker T, Morris DH, et al. Aerosol and surface stability of SARS-CoV-2 as compared with SARS-CoV-1. $N$ Engl J Med. 2020;382(16):1564-1567. doi:10.1056/ NEJMc2004973

100. Ozdemir C, Kucuksezer UC, Tamay ZU. Is BCG vaccination affecting the spread and severity of COVID-19? Allergy. 2020;75(7):1824-1827. doi:10.1111/all.14344

101. Chang L, Yan Y, Wang L. Coronavirus disease 2019: coronaviruses and blood safety. Transfus Med Rev. 2020;34(2):75-80. doi:10.1016/j.tmrv.2020.02.003

102. Dodd RY, Stramer SL. COVID-19 and blood safety: help with a dilemma. Transfus Med Rev. 2020;34(2):73-74. doi:10.1016/j. tmrv.2020.02.004

103. Xia J, Tong J, Liu M, et al. Evaluation of coronavirus in tears and conjunctival secretions of patients with SARS-CoV-2 infection. $J$ Med Virol. 2020;92(6):589-594. doi:10.1002/jmv.25725

104. Tang A, Tong $Z$, Wang $H$, et al. Detection of novel coronavirus by RT-PCR in stool specimen from asymptomatic child, China. Emerg Infect Dis. 2020;26(6):1337-1339. doi:10.3201/ eid2606.200301 
105. Dong X, Cao Y, Lu X, et al. Eleven faces of coronavirus disease 2019. Allergy. 2020;75(7):1699-1709.

106. Xing Y, Ni W, Wu Q, et al. Prolonged presence of SARS-CoV-2 in feces of pediatric patients during the convalescent phase. medRxiv. 2020. doi:10.1101/2020.03.11.20033159

107. Levy A, Yagil Y, Bursztyn M, et al. ACE2 expression and activity are enhanced during pregnancy. Am J Physiol Regul Integr Comp Physiol. 2008;295(6):R1953-R61. doi:10.1152/ajpregu.90 592.2008

108. Li M, Chen L, Xiong C, Li X. The ACE2 expression of maternalfetal interface and fetal organs indicates potential risk of vertical transmission of SARS-COV-2. bioRxiv. 2020. doi:10.1101/ 2020.02.27.967760

109. Su H, Yang M, Wan C, et al. Renal histopathological analysis of 26 postmortem findings of patients with COVID-19 in China. Kidney Int. 2020;98(1):219-227. doi:10.1016/j.kint.2020.04.003

110. Zhang H, Zhou P, Wei Y, et al. Histopathologic changes and SARS-CoV-2 immunostaining in the lung of a patient with COVID-19. Ann Intern Med. 2020;172(9):629-632. doi:10.7326/ M20-0533

111. Grillo F, Barisione E, Ball L, et al. Lung fibrosis: an undervalued finding in COVID-19 pathological series. Lancet Infect Dis. 2021;21(4). doi:10.1016/S1473-3099(20)30582-X

112. Tian S, Hu W, Niu L, et al. Pulmonary pathology of early phase 2019 novel coronavirus (COVID-19) pneumonia in two patients with lung cancer. $J$ Thorac Oncol. 2020;15(5):700-704. doi:10.1016/j.jtho.2020.02.010

113. Wang C, Xie J, Zhao L, et al. Alveolar macrophage dysfunction and cytokine storm in the pathogenesis of two severe COVID-19 patients. EBioMedicine. 2020;57:102833. doi:10.1016/j. ebiom.2020.102833

114. Wichmann D, Sperhake J-P, Lütgehetmann M, et al. Autopsy findings and venous thromboembolism in patients with COVID-19: a prospective cohort study. Ann Intern Med. 2020;173(4):268-277.

115. Zhao CL, Rapkiewicz A, Maghsoodi-Deerwester M, et al. Pathological findings in the postmortem liver of COVID-19 patients. Hum Pathol. 2021;109:59-68. doi:10.1016/j. humpath.2020.11.015

116. Jaunmuktane Z, Mahadeva U, Green A, et al. Microvascular injury and hypoxic damage: emerging neuropathological signatures in COVID-19. Acta Neuropathol. 2020;140(3):397-400. doi:10.1007/s00401-020-02190-2

117. Reichard RR, Kashani KB, Boire NA, et al. Neuropathology of COVID-19: a spectrum of vascular and acute disseminated encephalomyelitis (ADEM)-like pathology. Acta Neuropathol. 2020;140(1):1-6. doi:10.1007/s00401-020-02166-2

118. Bradley BT, Maioli H, Johnston R, et al. Histopathology and ultrastructural findings of fatal COVID-19 infections in Washington State: a case series. Lancet. 2020;396(10247):320332. doi:10.1016/S0140-6736(20)31305-2

119. Menter T, Haslbauer JD, Nienhold R, et al. Postmortem examination of COVID-19 patients reveals diffuse alveolar damage with severe capillary congestion and variegated findings in lungs and other organs suggesting vascular dysfunction. Histopathology. 2020;77(2):198-209. doi:10.1111/his.14134

120. Li Y, Li M, Wang M, et al. Acute cerebrovascular disease following COVID-19: a single center, retrospective, observational study. Stroke Vasc Neurol. 2020;5(3):279-284. doi:10.1136/svn-2020000431

121. Winata S, Kurniawan A. Coagulopathy in COVID-19: a systematic review. Medicinus. 2021;8(2):72-80. doi:10.19166/med. v8i2.3444
122. Ribes A, Vardon-Bounes F, Mémier V, et al. Thromboembolic events and Covid-19. Adv Biol Regul. 2020;77:100735. doi:10.1016/j.jbior.2020.100735

123. Tang N, Li D, Wang X, Sun Z. Abnormal coagulation parameters are associated with poor prognosis in patients with novel coronavirus pneumonia. J Thromb Haemost. 2020;18(4):844-847. doi:10.1111/jth. 14768

124. Deshpande C. Thromboembolic findings in COVID-19 autopsies: pulmonary thrombosis or embolism? Ann Intern Med. 2020;173 (5):394-395. doi:10.7326/M20-3255

125. McIntosh K, Hirsch M, Bloom A. Coronavirus disease 2019 (COVID-19). UpToDate; February, 2020.

126. Control CfD, Prevention. Evaluating and testing persons for coronavirus disease 2019 (COVID-19). National Center for Immunization and Respiratory Diseases (NCIRD), Division of Viral Diseases; 2020.

127. America IDSo. COVID-19 prioritization of diagnostic testing; 2020.

128. Guan W-J, Ni Z-Y, Hu Y, et al. Clinical characteristics of coronavirus disease 2019 in China. $N$ Engl J Med. 2020;382 (18):1708-1720. doi:10.1056/NEJMoa2002032

129. Zhu N, Zhang D, Wang W; China Novel Coronavirus Investigating and Research Team. A novel coronavirus from patients with pneumonia in China. $N$ Engl $J$ Med. 2019;382:727-733.

130. Capobianchi MR, Rueca M, Messina F, et al. Molecular characterization of SARS-CoV-2 from the first case of COVID-19 in Italy. Clin Microbiol Infect. 2020;26(7):954-956. doi:10.1016/j. cmi.2020.03.025.

131. Shu Y, McCauley J. GISAID: global initiative on sharing all influenza data-from vision to reality. Eurosurveillance. 2017;22 (13):30494. doi:10.2807/1560-7917.ES.2017.22.13.30494

132. Binnicker MJ. Emergence of a novel coronavirus disease (COVID-19) and the importance of diagnostic testing: why partnership between clinical laboratories, public health agencies, and industry is essential to control the outbreak. Clin Chem. 2020;66 (5):664-666. doi:10.1093/clinchem/hvaa071

133. Interim guidelines for collecting, handling, and testing clinical specimens from persons for coronavirus disease 2019. [database on the Internet]; 2020 [cited April 6, 2020]. Available from: https://www.cdc.gov/coronavirus/2019-ncov/lab/guidelines-clini cal-specimens.html. Accessed November 22, 2021.

134. Return-to-work criteria for healthcare workers | [database on the Internet]; 2020 [cited April 15, 2020]. Available from: https:// www.cdc.gov/coronavirus/2019-ncov/hcp/return-to-work.html?. Accessed November 22, 2021.

135. World Health Organization. Home care for patients with COVID19 presenting with mild symptoms and management of their contacts: interim guidance; 2020. Available from: who.int/publica tions/i/item/home-care-for-patients-with-suspected-novel-corona virus-(ncov)-infection-presenting-with-mild-symptoms-and-man agement-of-contacts. Accessed November 30, 2021.

136. Woelfel R, Corman VM, Guggemos W, et al. Clinical presentation and virological assessment of hospitalized cases of coronavirus disease 2019 in a travel-associated transmission cluster. MedRxiv. 2020. doi:10.1101/2020.03.05.20030502

137. Carver C, Jones N Comparative accuracy of oropharyngeal and nasopharyngeal swabs for diagnosis of COVID-19. Centre for Evidence-Based Medicine, Nuffield Department of Primary Care Health Sciences, University of Oxford; 2020.

138. World Health Organization. Laboratory testing for coronavirus disease 2019 (COVID-19) in suspected human cases: interim guidance, 2 March 2020. World Health Organization; 2020. 
139. Holshue ML, DeBolt C, Lindquist S, et al. First case of 2019 novel coronavirus in the United States. $N$ Engl J Med. 2020;382 (10):929-936. doi:10.1056/NEJMoa2001191

140. Zhang W, Du R-H, Li B, et al. Molecular and serological investigation of 2019-nCoV infected patients: implication of multiple shedding routes. Emerg Microbes Infect. 2020;9(1):386-389. doi:10.1080/22221751.2020.1729071

141. Linton NM, Kobayashi T, Yang Y, et al. Incubation period and other epidemiological characteristics of 2019 novel coronavirus infections with right truncation: a statistical analysis of publicly available case data. J Clin Med. 2020;9(2):538. doi:10.3390/jcm9020538

142. Guglielmi G. First CRISPR test for the coronavirus approved in the United States. Nature (Lond). 2020. doi:10.1038/d41586-02001402-9

143. Pascarella G, Strumia A, Piliego C, et al. COVID-19 diagnosis and management: a comprehensive review. $J$ Intern Med. 2020;288(2):192-206. doi:10.1111/joim.13091

144. Broughton JP, Deng X, Yu G, et al. Rapid detection of 2019 novel coronavirus SARS-CoV-2 using a CRISPR-based DETECTR lateral flow assay. MedRxiv. 2020. doi:10.1101/2020.03.06.20032334

145. Yang X, Yu Y, Xu J, et al. Clinical course and outcomes of critically ill patients with SARS-CoV-2 pneumonia in Wuhan, China: a single-centered, retrospective, observational study. Lancet Respir Med. 2020;8(5):475-481. doi:10.1016/S22132600(20)30079-5

146. Ai T, Yang Z, Hou H, et al. Correlation of chest CT and RT-PCR testing in coronavirus disease 2019 (COVID-19) in China: a report of 1014 cases. Radiology. 2020;296:E32-E40. doi:10.1148/radiol.2020200642

147. Simpson S, Kay FU, Abbara S, et al. Radiological society of north America expert consensus document on reporting chest CT findings related to COVID-19: endorsed by the society of thoracic Radiology, the American college of Radiology, and RSNA. Radiol Cardiothorac Imaging. 2020;2(2):e200152. doi:10.1148/ryct.2020200152

148. Song F, Shi N, Shan F, et al. Emerging 2019 novel coronavirus (2019-nCoV) pneumonia. Radiology. 2020;295(1):210-217. doi:10.1148/radiol.2020200274

149. Bai HX, Hsieh B, Xiong Z, et al. Performance of radiologists in differentiating COVID-19 from viral pneumonia on chest CT. Radiology. 2020;296:E46-54.

150. Zheng C, Ye T, Sun P. Time course of lung changes at chest CT during recovery from coronavirus disease 2019 (COVID-19). Radiology. 2020;295:715-721. doi:10.1148/radiol.2020200370

151. Shi H, Han X, Jiang N, et al. Radiological findings from 81 patients with COVID-19 pneumonia in Wuhan, China: a descriptive study. Lancet Infect Dis. 2020;20(4):425-434. doi:10.1016/ S1473-3099(20)30086-4

152. Zhao W, Zhong Z, Xie X, et al. Relation between chest CT findings and clinical conditions of coronavirus disease (COVID19) pneumonia: a multicenter study. Am J Roentgenol. 2020;214 (5):1072-1077. doi:10.2214/AJR.20.22976

153. Huang P, Liu T, Huang L, et al. Use of chest CT in combination with negative RT-PCR assay for the 2019 novel coronavirus but high clinical suspicion. Radiology. 2020;295(1):22-23. doi:10.1148/radiol.2020200330

154. Brogna B, Bignardi E, Brogna C, et al. Typical CT findings of COVID-19 pneumonia in patients presenting with repetitive negative RT-PCR. Radiography. 2021;27(2):743-747. doi:10.1016/j. radi.2020.09.012

155. Gervaise A, Bouzad C, Peroux E, Helissey C. Acute pulmonary embolism in non-hospitalized COVID-19 patients referred to CTPA by emergency department. Eur Radiol. 2020;30:61706177. doi:10.1007/s00330-020-06977-5
156. Minuz P, Mansueto G, Mazzaferri F, et al. High rate of pulmonary thromboembolism in patients with SARS-CoV-2 pneumonia. Clin Microbiol Infect. 2020;26(11):1572-1573. doi:10.1016/j. cmi.2020.06.011

157. Xing C, Li Q, Du H, et al. Lung ultrasound findings in patients with COVID-19 pneumonia. Crit Care. 2020;24(1):1-3. doi:10.1186/s13054-020-02876-9

158. Buonsenso D, Piano A, Raffaelli F, et al. novel coronavirus disease-19 pnemoniae: a case report and potential applications during COVID-19 outbreak. Eur Rev Med Pharmacol Sci. 2020;24:2776-2780. doi:10.26355/eurrev_202003_20549

159. Soldati G, Smargiassi A, Inchingolo R, et al. Proposal for international standardization of the use of lung ultrasound for patients with COVID-19: a simple, quantitative, reproducible method. $J$ Ultrasound Med. 2020;39(7):1413-1419. doi:10.1002/jum.15285

160. Pourbagheri-Sigaroodi A, Bashash D, Fateh F, Abolghasemi H. Laboratory findings in COVID-19 diagnosis and prognosis. Clin Chim Acta. 2020;510:475-482. doi:10.1016/j.cca.2020.08.019

161. Hassan SA, Sheikh FN, Jamal S, et al. Coronavirus (COVID-19): a review of clinical features, diagnosis, and treatment. Cureus. 2020;12(3):e-7355.

162. Li Z, Yi Y, Luo X, et al. Development and clinical application of a rapid IgM-IgG combined antibody test for SARS-CoV-2 infection diagnosis. J Med Virol. 2020;92(9):1518-1524.

163. Long Q-X, Liu B-Z, Deng H-J, et al. Antibody responses to SARS-CoV-2 in patients with COVID-19. Nat Med. 2020;26 (6):845-848. doi:10.1038/s41591-020-0897-1

164. Meyer B, Drosten C, Müller MA. Serological assays for emerging coronaviruses: challenges and pitfalls. Virus Res. 2014;194:175183. doi:10.1016/j.virusres.2014.03.018

165. FDA U. Coronavirus (COVID-19) update: FDA authorizes first antigen test to help in the rapid detection of the virus that causes COVID-19 in patients; 2020.

166. Mathuria JP, Yadav R. Laboratory diagnosis of SARS-CoV-2-a review of current methods. J Infect Public Health. 2020;13 (7):901-905. doi:10.1016/j.jiph.2020.06.005

167. Lansbury L, Lim B, Baskaran V, Lim WS. Co-infections in people with COVID-19: a systematic review and meta-analysis. $J$ Infect. 2020;81(2):266-275. doi:10.1016/j.jinf.2020.05.046

168. Contou D, Claudinon A, Pajot O, et al. Bacterial and viral coinfections in patients with severe SARS-CoV-2 pneumonia admitted to a French ICU. Ann Intensive Care. 2020;10(1):1-9. doi:10.1186/s13613-020-00736-X

169. Baunoch D, Wolfe A, Wang D, et al. Co-occurrence of SARSCoV-2 and respiratory pathogens in the Frail elderly. medRxiv. 2020. doi:10.1101/2020.06.24.20138941

170. Bordi L, Nicastri E, Scorzolini L, et al. Differential diagnosis of illness in patients under investigation for the novel coronavirus (SARS-CoV-2), Italy, February 2020. Eurosurveillance. 2020;25 (8):2000170. doi:10.2807/1560-7917.ES.2020.25.8.2000170

171. Boers SA, Melchers WJ, Peters CJ, et al. Multicenter evaluation of QIAstat-Dx respiratory panel V2 for detection of viral and bacterial respiratory pathogens. J Clin Microbiol. 2020;58(6). doi:10.1128/JCM.01793-19

172. Walker M. Flu, COVID-19 or Both? Don't Overlook CoInfection. Urges C, editor. Medpage Today; 2020.

173. Garcia-Vidal C, Sanjuan G, Moreno-García E, et al. Incidence of co-infections and superinfections in hospitalized patients with COVID-19: a retrospective cohort study. Clin Microbiol Infect. 2021;27(1):83-88. doi:10.1016/j.cmi.2020.07.041

174. Lai -C-C, Wang C-Y, Hsueh P-R. Co-infections among patients with COVID-19: the need for combination therapy with non-antiSARS-CoV-2 agents? J Microbiol Immunol Infect. 2020;53 (4):505-512. doi:10.1016/j.jmii.2020.05.013 
175. Sharifipour E, Shams S, Esmkhani M, et al. Evaluation of bacterial co-infections of the respiratory tract in COVID-19 patients admitted to ICU. BMC Infect Dis. 2020;20(1):1-7. doi:10.1186/ s12879-020-05374-Z

176. Chen N, Zhou M, Dong X, et al. Epidemiological and clinical characteristics of 99 cases of 2019 novel coronavirus pneumonia in Wuhan, China: a descriptive study. Lancet. 2020;395 (10223):507-513. doi:10.1016/S0140-6736(20)30211-7

177. Nickel CH, Bingisser R. Mimics and chameleons of COVID-19. Swiss Med Wkly. 2020;150(1314):1-2.

178. Hu L, Chen S, Fu Y, et al. Risk factors associated with clinical outcomes in 323 coronavirus disease 2019 (COVID-19) hospitalized patients in Wuhan, China. Clin Infect Dis. 2020;71 (16):2089-2098. doi:10.1093/cid/ciaa539.

179. Yao-T-T, Qian J-D, Zhu W-Y, et al. A systematic review of lopinavir therapy for SARS coronavirus and MERS coronavirus-A possible reference for coronavirus disease-19 treatment option. J Med Virol. 2020;92(6):556-563. doi:10.1002/jmv.25729

180. Lu H. Drug treatment options for the 2019-new coronavirus (2019-nCoV). Biosci Trends. 2020;14(1):69-71. doi:10.5582/ bst.2020.01020

181. Cao B, Wang Y, Wen D. A trial of lopinavir-ritonavir in adults hospitalized with severe Covid-19. $N$ Engl J Med. 2020;382:1708-1720. doi:10.1056/NEJMoa2001282

182. There is currently no strong evidence of lopinavir/ritonavir in the treatment of COVID-10. [database on the Internet]. The Centre for Evidence-Based Medicine; 2020. Available from: https:// www.cebm.net/covid-19/lopinavir-ritonavir-a-rapid-review-ofthe-evidence-for-effectiveness-in-treating-covid/. Accessed November 22, 2021.

183. Yan D, Liu X-Y, Zhu Y-N, et al. Factors associated with prolonged viral shedding and impact of Lopinavir/Ritonavir treatment in patients with SARS-CoV-2 infection. medRxiv. 2020. doi:10.1101/2020.03.22.20040832

184. Hariyanto TI, Kristine E, Hardi J, Kurniawan A. Efficacy of Lopinavir/Ritonavir compared with standard care for treatment of coronavirus disease 2019 (COVID-19): a systematic review. Infect Disord Drug Targets. 2021;21(5):e270421187364. doi:10.2174/ 1871526520666201029125725

185. Shen K, Yang Y, Wang T, et al. Diagnosis, treatment, and prevention of 2019 novel coronavirus infection in children: experts' consensus statement. World J Pediatr. 2020:1-9. doi:10.1007/ s12519-020-00340-w

186. Pereda R, González D, Rivero HB, et al. Therapeutic effectiveness of interferon- $\alpha 2 b$ against COVID-19: the Cuban experience. J Interferon Cytokine Res. 2020;40(9):438-442. doi:10.1089/ jir.2020.0124

187. Wang B, Li D, Liu T, et al. Subcutaneous injection of IFN alpha2b for COVID-19: an observational study. BMC Infect Dis. 2020;20(1):1-6. doi:10.1186/s12879-020-05425-5

188. Madsen LW. Remdesivir for the treatment of covid-19-final report. N Engl J Med. 2020;338(19):1813-1826.

189. Wang M, Cao R, Zhang L, et al. Remdesivir and chloroquine effectively inhibit the recently emerged novel coronavirus (2019nCoV) in vitro. Cell Res. 2020;30(3):269-271. doi:10.1038/ s41422-020-0282-0

190. Negahdaripour M. The rise and fall in therapeutic candidates for COVID-19. Iran J Med Sci. 2020;45(4):231-232. doi:10.30476/ ijms.2020.46689

191. World Health Organization. WHO recommends against the use of remdesivir in COVID-19 patients; 2020.

192. Hariyanto TI, Kwenandar F, Japar KV, et al. The Effectiveness and safety of remdesivir for the treatment of patients with COVID-19: a systematic review and meta-analysis. Anti Infect Agents. 2021;19 (3):333-340. doi:10.2174/2211352518999201009124433
193. Martinez MA. Compounds with therapeutic potential against novel respiratory 2019 coronavirus. Antimicrob Agents Chemother. 2020;64(5). doi:10.1128/AAC.00399-20

194. Zhou F, Yu T, Du R, et al. Clinical course and risk factors for mortality of adult inpatients with COVID-19 in Wuhan, China: a retrospective cohort study. Lancet. 2020;395(10229):1054-1062. doi:10.1016/S0140-6736(20)30566-3

195. Hernandez AV, Roman YM, Pasupuleti V, Barboza JJ, White CM. Hydroxychloroquine or chloroquine for treatment or prophylaxis of COVID-19: a living systematic review. Ann Intern Med. 2020;173(4):287-296. doi:10.7326/M20-2496

196. Zhan X, Dowell S, Shen Y, Lee DL. Chloroquine to fight COVID-19: a consideration of mechanisms and adverse effects? Heliyon. 2020;6(9):e04900. doi:10.1016/j.heliyon.2020.e04900

197. Boriskin Y, Leneva I, Pecheur E-I, Polyak S. Arbidol: a broadspectrum antiviral compound that blocks viral fusion. Curr Med Chem. 2008;15(10):997-1005. doi:10.2174/092986708784049658

198. Zhu Z, Lu Z, Xu T, et al. Arbidol monotherapy is superior to lopinavir/ritonavir in treating COVID-19. J Infect. 2020;81(1): e21-e3. doi:10.1016/j.jinf.2020.03.060

199. Furuta Y, Komeno T, Nakamura T. Favipiravir (T-705), a broad spectrum inhibitor of viral RNA polymerase. Proc Jpn Acad Series B. 2017;93(7):449-463. doi:10.2183/pjab.93.027

200. Agrawal U, Raju R, Udwadia ZF. Favipiravir: a new and emerging antiviral option in COVID-19. Med J Armed Forces India. 2020;76(4):370-376. doi:10.1016/j.mjafi.2020.08.004

201. Wang Y, Jiang W, He Q, et al. Early, low-dose and short-term application of corticosteroid treatment in patients with severe COVID-19 pneumonia: single-center experience from Wuhan, China. medRxiv. 2020. doi:10.1101/2020.03.06.20032342

202. Headquarters NNIo. COVID-19 treatment guidelines. Corticosteroids; 2020. Available from: https://www.covid19treat mentguidelines.nih.gov/immune-based-therapy/immunomodula tors/corticosteroids/. Accessed November 22, 2021.

203. Russell CD, Millar JE, Baillie JK. Clinical evidence does not support corticosteroid treatment for 2019-nCoV lung injury. Lancet. 2020;395(10223):473-475. doi:10.1016/S0140-6736(20) 30317-2

204. Nguyen AA, Habiballah SB, Platt CD, et al. Immunoglobulins in the treatment of COVID-19 infection: proceed with caution! Clin Immunol. 2020;216:108459. doi:10.1016/j.clim.2020.108459

205. Zhang J, Ma X, Yu F, et al. Teicoplanin potently blocks the cell entry of 2019-nCoV. BioRxiv. 2020. doi:10.1101/2020.02.05.935387

206. Zhou N, Pan T, Zhang J, et al. Glycopeptide antibiotics potently inhibit cathepsin 1 in the late endosome/lysosome and block the entry of Ebola virus, middle east respiratory syndrome coronavirus (MERS-CoV), and severe acute respiratory syndrome coronavirus (SARS-CoV). J Biol Chem. 2016;291(17):9218-9232. doi:10.1074/jbc.M116.716100

207. Baron SA, Devaux C, Colson P, et al. Teicoplanin: an alternative drug for the treatment of coronavirus COVID-19. Int J Antimicrob Agents. 2020;55:105944. doi:10.1016/j.ijantimicag.2020.105944

208. Mondal S, Quintili AL, Karamchandani K, Bose S. Thromboembolic disease in COVID-19 patients: a brief narrative review. J Intensive Care. 2020;8(1):1-10. doi:10.1186/s40560020-00483-y

209. Hippensteel JA, LaRiviere WB, Colbert JF, et al. Heparin as a therapy for COVID-19: current evidence and future possibilities. Am J Physiol Lung Cell Mol Physiol. 2020;319(2):L211-L7. doi:10.1152/ajplung.00199.2020

210. Atallah B, Mallah SI, AlMahmeed W. Anticoagulation in COVID-19. Oxford University Press; 2020.

211. Komiyama M, Hasegawa K. Anticoagulant therapy for patients with coronavirus disease 2019: urgent need for enhanced awareness. Eur Cardiol Rev. 2020;15. doi:10.15420/ecr.2020.24 
212. Magazine P. Aspirin could protect against severe COVID-19; 2020.

213. Daily S. Aspirin use significantly reduces risk of death in hospitalized COVID-19 patients; 2020.

214. Bianconi V, Violi F, Fallarino F, et al. Is acetylsalicylic acid a safe and potentially useful choice for adult patients with COVID-19? Drugs. 2020:1-14. doi:10.1007/s40265-019-01241-7

215. Caly L, Druce JD, Catton MG, et al. The FDA-approved drug ivermectin inhibits the replication of SARS-CoV-2 in vitro. Antiviral Res. 2020;178:104787. doi:10.1016/j.antiviral.2020.104787

216. Conversation T. Ivermectin is still not a miracle cure for COVID19, despite what you may have read; 2020.

217. Hariyanto TI, Halim DA, Rosalind J, et al. Ivermectin and outcomes from Covid-19 pneumonia: a systematic review and metaanalysis of randomized clinical trial studies. Rev Med Virol. 2021: e2265. doi: $10.1002 / \mathrm{rmv} .2265$

218. Tang Y, Liu J, Zhang D, et al. Cytokine storm in COVID-19: the current evidence and treatment strategies. Front Immunol. 2020;11:1708. doi:10.3389/fimmu.2020.01708

219. Reyes AZ, Hu KA, Teperman J, et al. Anti-inflammatory therapy for COVID-19 infection: the case for colchicine. Ann Rheum Dis. 2021;80(5):550-557. doi:10.1136/annrheumdis-2020-219174

220. Robb CT, Goepp M, Rossi AG, Yao C. Non-steroidal anti-inflammatory drugs, prostaglandins, and COVID-19. Br J Pharmacol. 2020;177(21):4899-4920. doi:10.1111/bph.15206

221. Day M. Covid-19: Ibuprofen Should Not Be Used for Managing Symptoms, Say Doctors and Scientists. British Medical Journal Publishing Group; 2020.

222. Schmack B, Weymann A, Lüdike P, et al. The Role of Mechanical Circulatory Support in COVID 19 Patients. Wiley Online Library; 2020.

223. Barbaro RP, MacLaren G, Boonstra PS, et al. Extracorporeal membrane oxygenation support in COVID-19: an international cohort study of the Extracorporeal Life Support Organization registry. Lancet. 2020;396(10257):1071-1078. doi:10.1016/S0140-6736 (20)32008-0

224. Madjid M, Safavi-Naeini P, Solomon SD, Vardeny O. Potential effects of coronaviruses on the cardiovascular system: a review. JAMA Cardiol. 2020;5(7):831-840. doi:10.1001/jamacardio.20 20.1286

225. Ranard LS, Fried JA, Abdalla M, et al. Approach to acute cardiovascular complications in COVID-19 infection. Circ Heart Fail. 2020;13(7):e007220.

doi: 10.1161 CIRCHEARTFAILURE. 120.007220

226. Temel S, Sungur M. Blood purification treatments in COVID-19. $J$ Crit Intensive Care. 2020;11(Supp.):32.

227. Yang X-H, Sun R-H, Zhao M-Y, et al. Expert recommendations on blood purification treatment protocol for patients with severe COVID-19. Chronic Dis Transl Med. 2020;6(2):106-114. doi:10.1016/j.cdtm.2020.04.002

228. Samaee H, Mohsenzadegan M, Ala S, et al. Tocilizumab for treatment patients with COVID-19: recommended medication for novel disease. Int Immunopharmacol. 2020;89:107018. doi:10.1016/j.intimp.2020.107018

229. Stone JH, Frigault MJ, Serling-Boyd NJ, et al. Efficacy of tocilizumab in patients hospitalized with Covid-19. $N$ Engl $J$ Med. 2020;383(24):2333-2344. doi:10.1056/NEJMoa2028836

230. Hariyanto TI, Hardyson W, Kurniawan A. Efficacy and safety of tocilizumab for coronavirus disease 2019 (Covid-19) patients: a systematic review and meta-analysis. Drug Res. 2021;71 (05):265-274. doi:10.1055/a-1336-2371

231. Marano G, Vaglio S, Pupella S, et al. Convalescent plasma: new evidence for an old therapeutic tool? Blood Transfus. 2016;14 (2):152. doi:10.2450/2015.0131-15
232. Rojas M, Rodríguez Y, Monsalve DM, et al. Convalescent plasma in Covid-19: possible mechanisms of action. Autoimmun Rev. 2020;19(7):102554. doi:10.1016/j.autrev.2020.102554

233. Chen L, Xiong J, Bao L, Shi Y. Convalescent plasma as a potential therapy for COVID-19. Lancet Infect Dis. 2020;20 (4):398-400. doi:10.1016/S1473-3099(20)30141-9

234. Ray I, Sánchez DF, Robert CA, Robert MP. Convalescent plasma therapy: an effective therapeutic option to treat COVID-19? A narrative review. Int $J$ Clin Transfus Med. 2020;8:7-21. doi:10.2147/IJCTM.S269691

235. Times TNY. Remdesivir fails to prevent covid-19 deaths in huge trial; 2020.

236. Callaway E. Russia's fast-track coronavirus vaccine draws outrage over safety. Nature. 2020;584(7821):334-335. doi:10.1038/ d41586-020-02386-2

237. Logunov DY, Dolzhikova IV, Zubkova OV, et al. Safety and immunogenicity of an rAd26 and rAd5 vector-based heterologous prime-boost COVID-19 vaccine in two formulations: two open, non-randomised Phase 1/2 studies from Russia. Lancet. 2020;396 (10255):887-897. doi:10.1016/S0140-6736(20)31866-3

238. Ivanova P, Sagdiev RE. Exclusive: Russia focuses on freeze-dried vaccine doses as transport fix. Moscow: Reuters; 2020.

239. Chowdhury AI. Role and effects of micronutrients supplementation in immune system and SARS-Cov-2 (COVID-19). Asian $J$ Immunol. 2020;4:47-55.

240. Jain A, Chaurasia R, Sengar NS, et al. Analysis of vitamin D level among asymptomatic and critically ill COVID-19 patients and its correlation with inflammatory markers. Sci Rep. 2020;10 (1):1-8. doi:10.1038/s41598-020-77093-z

241. Hariyanto TI, Intan D, Hananto JE, et al. Vitamin D supplementation and Covid-19 outcomes: a systematic review, meta-analysis and meta-regression. Rev Med Virol. 2021:e2269. doi:10.1002/rmv.2269

242. Grant WB, Lahore H, McDonnell SL, et al. Evidence that vitamin D supplementation could reduce risk of influenza and COVID-19 infections and deaths. Nutrients. 2020;12(4):988. doi:10.3390/ nu12040988

243. Ilie PC, Stefanescu S, Smith L. The role of vitamin D in the prevention of coronavirus disease 2019 infection and mortality. Aging Clin Exp Res. 2020;1-4. doi:10.1007/s40520-019-01392-3

244. Headquarters) NNIo. COVID-19 treatment guidelines. Vitamin C; 2020.

245. Hemilä H, Chalker E. Vitamin $\mathrm{C}$ as a possible therapy for COVID-19. Infect Chemother. 2020;52:281. doi:10.3947/ ic.2020.52.2.222

246. Colunga Biancatelli RML, Berrill M, Marik PE. The Antiviral Properties of Vitamin C. Taylor \& Francis; 2020.

247. Hemilä H, Chalker E. Vitamin C may reduce the duration of mechanical ventilation in critically ill patients: a meta-regression analysis. J Intensive Care. 2020;8(1):15. doi:10.1186/s40560020-0432-y

248. Carr AC, Rowe S. The emerging role of vitamin C in the prevention and treatment of COVID-19. Nutrients. 2020;12(11):3286. doi: $10.3390 /$ nu12113286

249. Hiedra R, Lo KB, Elbashabsheh M, et al. The use of IV vitamin C for patients with COVID-19: a case series. Expert Rev Anti Infect Ther. 2020;18(12):1259-1261. doi:10.1080/14787210.2020.1794819

250. Kaushik N, Subramani C, Anang S, et al. Zinc salts block hepatitis $\mathrm{E}$ virus replication by inhibiting the activity of viral RNAdependent RNA polymerase. J Virol. 2017;91(21). doi:10.1128/ JVI.00754-17

251. Bourinbaiar AS, Fruhstorfer EC. The effect of histamine type 2 receptor antagonists on human immunodeficiency virus (HIV) replication: identification of a new class of antiviral agents. Life Sci. 1996;59(23):PL365-PL70. doi:10.1016/S0024-3205(96) 00553-X 
252. Freedberg DE, Conigliaro J, Wang TC, et al. Famotidine use is associated with improved clinical outcomes in hospitalized COVID-19 patients: a propensity score matched retrospective cohort study. Gastroenterology. 2020;159(3):1129-1131.e3. doi:10.1053/j.gastro.2020.05.053
253. Janowitz T, Gablenz E, Pattinson D, et al. Famotidine use and quantitative symptom tracking for COVID-19 in non-hospitalised patients: a case series. Gut. 2020;69(9):1592-1597. doi:10.1136/ gutjnl-2020-321852

\section{Publish your work in this journal}

The International Journal of General Medicine is an international, peer-reviewed open-access journal that focuses on general and internal medicine, pathogenesis, epidemiology, diagnosis, monitoring and treatment protocols. The journal is characterized by the rapid reporting of reviews, original research and clinical studies across all disease areas. The manuscript management system is completely online and includes a very quick and fair peer-review system, which is all easy to use. Visit http://www.dovepress.com/ testimonials.php to read real quotes from published authors. 